\title{
ANALYSIS OF CHECK VALVE DISC MOTION \\ DURING A FLOW TRANSIENT \\ G. M. Fuls
}

December 1962

Contract NObs 78844

\author{
Price $\$ 1.00$ \\ Available from the Office of Technical Services, \\ Department of Commerce \\ Washington 25, D. C. \\ Printed In U. S. A.
}

This document is an interim memorandum prepared primarily for internal reference and does not represent a final expression of the opinion of Westinghouse. When this memorandum is distributed externally, it is with the express understanding that Westinghouse makes no representation as to completeness, accuracy, or usabilify of information contained therein.

\section{BETTIS ATOMIC POWER LABORATORY, PITTSBURGH, PA., OPERATED FOR THE U. S. ATOMIC ENERGY COMMISSION BY WESTINGHOUSE ELECTRIC CORPORATION}




\title{
SPECIAL EXTERNAL DISTRIBUTION
}

Manager, Pittsburgh Naval Reactors Office, AEC

Director, Development Division, PNRO

Argonne National Laboratory, W. F. Miller

Brookhaven National Laboratory, J. Chernick

Case Institute of Technology, R. S. Varga

David Taylor Model Basin, H. Polachek

Knolls Atomic Power Laboratory, R. Ehrlich

Los Alamos Scientific Laboratory, B. Carlson

New York University, R. Richtmyer

Oak Ridge National Laboratory, A. Householder

Philco Corporation, Computer Division, R. A. Cohen

Union Carbide Nuclear Company, K-25, V. E. Anderson

University of California Radiation Laboratory, Livermore,

S. Fernbach

1

Total

634

Copies of the computer program may be obtained from:

\author{
Manager, Marketing Services \\ Philco Corporation \\ Computer Division \\ 3900 Welsh Road \\ Willow Grove, Pennsylvania
}

Modifications, additions, and deletions made to the program by the originator will be automatically distributed via the Philco Corporation to organizations and individuals using the original program.

\section{LEGAL NOTICE}

This report was prepared as an account of Government sponsored work. Neither the United States, nor the United States Navy, nor the Commission, nor any person acting on behalf of these agencies:

A. Makes any warranty or representation, expressed or implied, with respect to the accuracy, completeness, or usefulness of the information contained in this report, or that the use of any information, apparatus, method, or process disclosed in this report may not infringe privately owned rights; or

B. Assumes any liabilities with respect to the use of, or for damages resulting from the use of any information, apparatus, method, or process disclosed in this report.

As used in the above, "person acting on behalf of these agencies" includes any employe or contractor of these agencies, or employe of such contractor, to the extent that such employe or contractor of these agencies, or employe of such contractor prepares, isseminates, or provides access to, any information pursuant to his employment or contract with the United States Navy or the Commission, or his employment with such contractor. 


\section{DISCLAIMER}

This report was prepared as an account of work sponsored by an agency of the United States Government. Neither the United States Government nor any agency Thereof, nor any of their employees, makes any warranty, express or implied, or assumes any legal liability or responsibility for the accuracy, completeness, or usefulness of any information, apparatus, product, or process disclosed, or represents that its use would not infringe privately owned rights. Reference herein to any specific commercial product, process, or service by trade name, trademark, manufacturer, or otherwise does not necessarily constitute or imply its endorsement, recommendation, or favoring by the United States Government or any agency thereof. The views and opinions of authors expressed herein do not necessarily state or reflect those of the United States Government or any agency thereof. 


\section{DISCLAIMER}

Portions of this document may be illegible in electronic image products. Images are produced from the best available original document. 


\section{CONTENTS}

Page No.

I. INTRODUCTION 1

II. ANALYSIS : 1

A. Method 1

B. Articulated and Linear Type Valves 6

C. Method of Solution by the SLAM Code 6

$\begin{array}{ll}\text { III. PROGRAM LIMITATIONS } & 7\end{array}$

$\begin{array}{lr}\text { IV. PROGRAM (CODE) IN PUT } & 7\end{array}$

V. TERMINOLOGY 14

$\begin{array}{ll}\text { VI. SOURCE DECK LISTING } & 16\end{array}$

$\begin{array}{ll}\text { VII. SAMPLE PROBLEM } & 34\end{array}$

A. Input 34

B. Output 35 
0

: 
This report contains an analysis of the dynamics of a check valve disc under the influence of a flow transient. The developed equations have been programed for the Philco-2000 digital computer in FORTRAN as the SLAM Code. The Code input consists of the characteristics of the valve and the flow transient. The output of the code includes the dynamics of the valve disc as a function of time and the pressirre surge induced by valve closure.

\section{ANALYSIS OF CHECK VALVE DISC MOTION \\ DURING A FLOW TRANSIENT}

$$
\text { G. M. Fuls }
$$

\section{INTRODUCTION}

The components of the main coolant system of a multiple loop pressurized water reactor plant are subjected to cyclic stresses when a check valve slams shut and produces a water hammer pressure surge. Fatigue failure under these conditions can be avoided by design, provided that the magnitudes of the stresses are known. Valve part stresses resulting from impact loads must also be known for proper design of the valve. These stresses can be calculated from the valve component velocities resulting from a flow transient on either closing or opening the valve.

This study predicts the impact velocities of the disc and the pressure surge resulting from extinguishing a fluid velocity. The numerical computations necessary for an iterative solution of the second order, nonlinear differential equation are performed by the SLAM Code (Bettis Code MO188),* utilizing the flow transient and the valve parameters which can be determined from the design of the valves.

\section{ANALYSIS}

\section{A. Method}

This analysis develops the equations of motion of a simple swing disc check valve from Newton's Second Law. After this development is complete, the modifications of the analysis necessary for application to other types of valves are described.

The basic assumptions necessary are as follows.

1. All valve springs are massless and linear.

2. The drag coefficient of the valve disc for a given orientation with respect to flow is independent of whether the flow is forward or reverse.

* The SLAM Code is an extension of a valve analysis originally performed at Knolls Atomic Power Laboratory. 
3. The added inertia of the disc resulting from the fact that the disc is in water is independent of whether the flow is forward or reverse.

4. Friction other than that resulting from viscous effects of the fluid is negligible.

For a rotating mass, Newton's Second Law takes the form

$$
J \ddot{\theta}=\mathrm{T}
$$

where $\mathrm{J}$ is the disc moment of inertia, $\ddot{\theta}$ is the disc angular acceleration, and $\mathrm{T}$ is the torque.

The torques acting on the disc during a transient are those caused by spring displacement, drag on the disc as a result of a relative velocity between the disc and the fluid, and the buoyant weight of the disc. The spring torque is the product of the spring constant and the angular displacement of the spring. Thus,

$$
\mathrm{T}_{\mathbf{s}}=\mathbf{k}_{\mathbf{s}}\left(\theta_{\mathrm{I}}-\theta\right)
$$

where $\mathrm{T}_{\mathrm{S}}$ is the spring torque, $\mathrm{k}_{\mathrm{S}}$ is the spring constant, $\theta$ is the angular displacement of the disc, and $\theta_{\mathrm{I}}$ is the initial angular spring displacement. The valve parameters for a simple swing disc check valve are shown in Figure 1.

The disc weight torque is equal to the product of the buoyant weight of the disc, the distance from the pivot point to the center of gravity of the disc, and the sine of the angle this line makes with the vertical. Thus,

$$
\mathrm{T}_{\mathrm{W}}=-\mathrm{W}_{\mathrm{b}} \overline{\mathrm{r}} \operatorname{Sin} \theta
$$

where $T_{W}$ is the disc weight torque, $W_{b}$ is the buoyant weight of the disc, $\bar{r}$ is the radial distance from the center of gravity to the pivot point, and $\theta$ is the angular displacement of the disc from the vertical line down from the pivot point and is positive in the opening direction of the disc.

The drag of the disc is equal to the product of the drag coefficient and the square of the velocity of the disc relative to the fluid. Thus,

$$
\mathrm{D}=(\mathrm{K} / 2 \mathrm{~g})\left(\mathrm{V}_{\mathrm{R}}\right)^{2}
$$

where $D$ is the drag, $K$ is the drag coefficient, $g$ is the gravitational constant, and $V_{R}$ is the relative velocity which is positive in the opening direction of the valve.

If the thickness of the disc is small in comparison with its face area, the disc may be treated as a surface; the magnitude of the absolute velocity of this surface is equal to the product of the angular velocity of the disc and the radial distance from the pivot point about which it rotates to the center of area of the disc surface. Thus,

$$
\mathrm{V}_{\mathrm{D}}=\mathrm{r}_{\mathrm{p}} \dot{\theta} / 12
$$

where $V_{D}$ is the magnitude of the vector velocity of the disc, $r_{p}$ is the radial distance from the pivot point to the center of the disc face area, and $\dot{\theta}$ is the angular velocity of the disc.

Thus, the velocity vector of the disc relative to the fluid is

$$
\overrightarrow{\mathrm{V}}_{\mathrm{R}}=\overrightarrow{\mathrm{V}}_{\mathrm{F}}-\overrightarrow{\mathrm{V}}_{\mathrm{D}}
$$




\section{-}

This report contains an analysis of the dynamics of a check valve disc under the influence of a flow transient. The developed equations have been programed for the Philco-2000 digital computer in FORTRAN as the SLAM Code. The Code input consists of the characteristics of the valve and the flow transient. The output of the code includes the dynamics of the valve disc as a function of time and the pressire surge induced by valve closure.

\section{ANALYSIS OF CHECK VALVE DISC MOTION DURING A FLOW TRANSIENT}

$$
\text { G. M. Fuls }
$$

\section{INTRODUC TION}

The components of the main coolant system of a multiple loop pressurized water reactor plant are subjected to cyclic stresses when a check valve slams shut and produces a water hammer pressure surge. Fatigue failure under these conditions can be avoided by design, provided that the magnitudes of the stresses are known. Valve part stresses resulting from impact loads must also be known for proper design of the valve. These stresses can be calculated from the valve component velocities resulting from a flow transient on either closing or opening the valve.

This study predicts the impact velocities of the disc and the pressure surge resulting from extinguishing a fluid velocity. The numerical computations necessary for an iterative solution of the second order, nonlinear differential equation are performed by the SLAM Code (Bettis Code MO188), * utilizing the flow transient and the valve parameters which can be determined from the design of the valves.

\section{ANALYSIS}

A. Method

This analysis develops the equations of motion of a simple swing disc check valve from Newton's Second Law. After this development is complete, the modifications of the analysis necessary for application to other types of valves are described.

The basic assumptions necessary are as follows.

1. All valve springs are massless and linear.

2. The drag coefficient of the valve disc for a given orientation with respect to flow is independent of whether the flow is forward or reverse.

\footnotetext{
* The SLAM Code is an extension of a valve analysis originally performed at Knolls Atomic Power Laboratory.
} 
3. The added inertia of the disc resulting from the fact that the disc is in water is independent of whether the flow is forward or reverse.

4. Friction other than that resulting from viscous effects of the fluid is negligible.

For a rotating mass, Newton's Second Law takes the form

$$
\mathrm{J} \ddot{\theta}=\mathrm{T},
$$

where $J$ is the disc moment of inertia, $\ddot{\theta}$ is the disc angular acceleration, and $\mathrm{T}$ is the torque.

The torques acting on the disc during a transient are those caused by spring displacement, drag on the disc as a result of a relative velocity between the disc and the fluid, and the buoyant weight of the disc. The spring torque is the product of the spring constant and the angular displacement of the spring. Thus,

$$
\mathrm{T}_{\mathbf{s}}=\mathbf{k}_{\mathbf{s}}\left(\theta_{\mathrm{I}}-\theta\right)
$$

where $\mathrm{T}_{\mathbf{s}}$ is the spring torque, $\mathrm{k}_{\mathrm{S}}$ is the spring constant, $\theta$ is the angular displacement of the disc, and $\theta_{I}$ is the initial angular spring displacement. The valve parameters for a simple swing disc check valve are shown in Figure 1.

The disc weight torque is equal to the product of the buoyant weight of the disc, the distance from the pivot point to the center of gravity of the disc, and the sine of the angle this line makes with the vertical. Thus,

$$
\mathrm{T}_{\mathrm{W}}=-\mathrm{W}_{\mathrm{b}} \overline{\mathrm{r}} \sin \theta
$$

where $T_{W}$ is the disc weight torque, $W_{b}$ is the buoyant weight of the disc, $\bar{r}$ is the radial distance from the center of gravity to the pivot point, and $\theta$ is the angular displacement of the disc from the vertical line down from the pivot point and is positive in the opening direction of the disc.

The drag of the disc is equal to the product of the drag coefficient and the square of the velocity of the disc relative to the fluid. Thus,

$$
\mathrm{D}=(\mathrm{K} / 2 \mathrm{~g})\left(\mathrm{V}_{\mathrm{R}}\right)^{2}
$$

where $\mathrm{D}$ is the drag, $\mathrm{K}$ is the drag coefficient, $\mathrm{g}$ is the gravitational constant, and $V_{R}$ is the relative velocity which is positive in the opening direction of the valve.

If the thickness of the disc is small in comparison with its face area, the disc may be treated as a surface; the magnitude of the absolute velocity of this surface is equal to the product of the angular velocity of the disc and the radial distance from the pivot point about which it rotates to the center of area of the disc surface. Thus,

$$
\mathrm{V}_{\mathrm{D}}=\mathrm{r}_{\mathrm{p}} \dot{\theta} / \mathbf{1 2}
$$

where $V_{D}$ is the magnitude of the vector velocity of the disc, $r_{p}$ is the radial distance from the pivot point to the center of the disc face area, and $\dot{\theta}$ is the angular velocity of the disc.

Thus, the velocity vector of the disc relative to the fluid is

$$
\overrightarrow{\mathrm{V}}_{\mathrm{R}}=\overrightarrow{\mathrm{V}}_{\mathrm{F}}-\overrightarrow{\mathrm{V}}_{\mathrm{D}}
$$




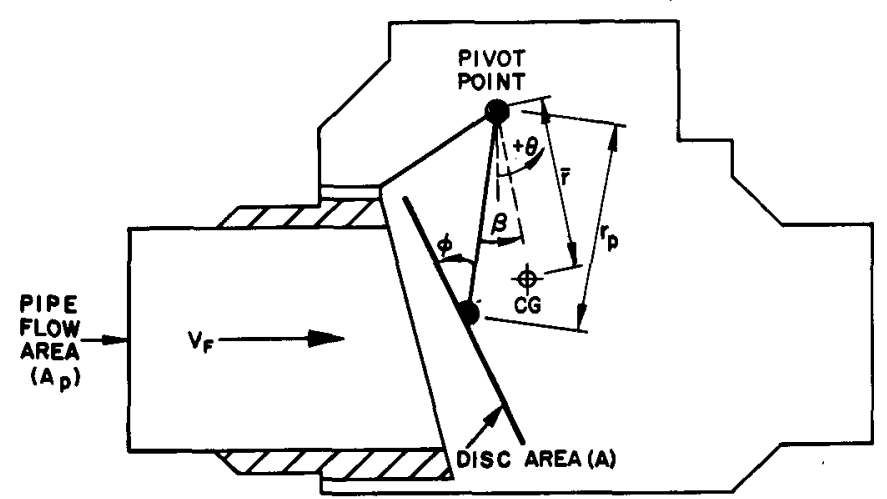

Figure 1. Simple Swing Disc Check Valve. where $\vec{V}_{F}$ is the velocity vector of the fluid and $\vec{V}_{R}$ is the relative velocity vector.

It is assumed that the path of the center of disc area lies in a plane and that the axis of the check valve also lies in the same plane. A set of coordinates is chosen such that the X-axis is coincidental with the axis of the check valve, and such that the $Y$-axis (positive in the direction of the disc pivot point) lies in the plane of the path of the center of the disc (Figure 2). Then, the relative velocity may be written

$$
\overrightarrow{\mathrm{V}}_{\mathrm{R}}=\left(\left|\mathrm{V}_{\mathrm{F}}\right| \overrightarrow{\mathrm{i}}+\overrightarrow{0 \mathrm{j}}\right)-\left(\left|\overrightarrow{\mathrm{V}}_{\mathrm{D}}\right| \operatorname{Cos} \eta \overrightarrow{\mathrm{i}}+\left|\overrightarrow{\mathrm{V}}_{\mathrm{D}}\right| \operatorname{Sin} \overrightarrow{\eta \mathrm{j}}\right) \text {, }
$$

where $\vec{i}$ is the unit vector along the X-axis, $\vec{j}$ is the unit vector along the $Y$-axis, $V_{F}$ is the fluid velocity, and $\eta$ is the angle between the disc velocity vector and the X-axis. Since the fluid velocity is parallel to the $\mathrm{X}$-axis, the vertical component of the fluid velocity is zero.

Rewriting Equation (3) and substituting from Equation (2),

$$
\overrightarrow{\mathrm{V}}_{\mathrm{R}}=\left(\mathrm{v}_{\mathrm{F}}-\frac{\mathrm{r}_{\mathrm{p}} \dot{\theta}}{12} \operatorname{Cos} \eta\right) \overrightarrow{\mathrm{i}}-\left(\frac{\mathrm{r}_{\mathrm{p}} \dot{\theta}}{12} \operatorname{Sin} \eta\right) \overrightarrow{\mathrm{j}}
$$

The angle the vector $\overrightarrow{\mathrm{V}}_{\mathrm{R}}$ makes with the $\mathrm{X}$-axis is

$$
\gamma=\operatorname{Tan}^{-1}\left(\frac{-\mathrm{r}_{\mathrm{p}} \dot{\theta} \sin \eta}{\mathrm{V}_{\mathrm{F}}-\frac{\mathrm{r}_{\mathrm{p}} \dot{\theta}}{12} \operatorname{Cos} \eta}\right) \text {. }
$$

Defining $\phi$ as the angle measured from $\bar{r}$ to the disc face, positive in the same direction as $\theta$, and $\beta$ as the angle measured from $r_{p}$ to $\bar{r}$, also positive in the same direction as $\theta$, then the angle $\chi$ between the perpendicular to the disc face and the relative velocity vector is

$$
\chi=\phi+\theta-\gamma
$$

and

$$
\eta=\theta-\beta
$$

It is assumed that the velocity of the disc relative to the fluid results in a single force which is perpendicular to the disc face and proportional to the square of the magnitude of the relative velocity. With this assumption

$$
\mathrm{D}_{\mathrm{F}}=\frac{\mathrm{K} \rho \mathrm{A}}{144(2 \mathrm{~g})}\left(\left|\mathrm{V}_{\mathrm{R}}\right|\right)^{2}
$$

where $D_{F}$ is the net drag force on the disc, $\rho$ is the density of the fluid, $V_{R}=\left|\vec{V}_{R}\right|$, g is the gravitational constant, and $\mathrm{A}$ is the area of the disc face. The moment or torque exerted by this force is equal to the 


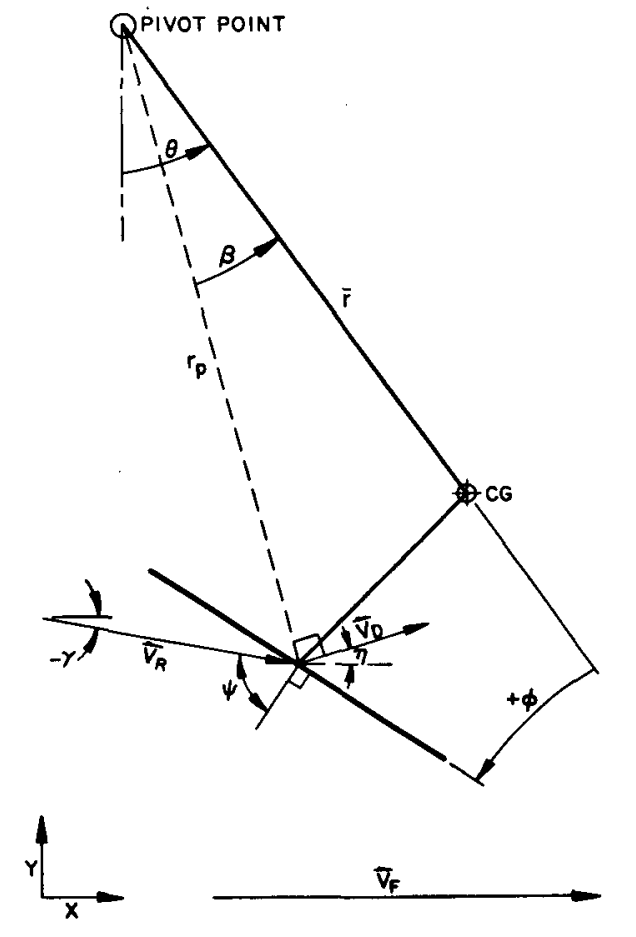

Figure 2. Force Diagram.

product of the net force, the radius arm, and the cosine of the angle $\phi+\beta$, or

$$
\mathrm{T}_{\mathrm{D}}=\mathrm{D}_{\mathbf{F}} \mathrm{r}_{\mathbf{p}} \operatorname{Cos}(\phi+\beta)
$$

where $T_{D}$ is the torque on the disc due to the viscosity of the fluid.

Substituting,

$$
\mathrm{T}_{\mathrm{D}}=\frac{\mathrm{K} \rho \mathrm{A}}{144(2 \mathrm{~g})}\left(\left|\overrightarrow{\mathrm{V}}_{\mathrm{R}}\right|\right)^{2} \mathrm{r}_{\mathrm{p}} \operatorname{Cos}(\phi+\beta)
$$

and substituting again from Equations (4) and (7),

$$
\begin{aligned}
\mathrm{T}_{\mathrm{D}} & =\frac{\mathrm{K} \rho \mathrm{A}}{144(2 \mathrm{~g})}\left\{\left[\mathrm{V}_{\mathrm{F}}-\frac{\mathrm{r}_{\mathrm{p}} \dot{\theta}}{12} \operatorname{Cos}(\theta-\beta)\right]^{2}\right. \\
& \left.+\left[\frac{\mathrm{r}_{\mathrm{p}} \dot{\theta}}{12} \operatorname{Sin}(\theta-\beta)\right]^{2}\right\} \mathrm{r}_{\mathrm{p}} \operatorname{Cos}(\phi+\beta) .
\end{aligned}
$$

Equation (8) represents the drag torque on the disc. The drag coefficient is determined by the angle $X$ between the vertical to the disc face and the relative velocity. This angle is given by a combination of Equations (5), (6), and (7). Thus,

$$
\chi=\phi+\theta-\operatorname{Tan}^{-1}\left[\frac{-12 \mathrm{r}_{\mathrm{p}} \dot{\theta} \operatorname{Sin}(\theta-\beta)}{12 \mathrm{~V}_{\mathrm{F}}-\mathrm{r}_{\mathrm{p}} \dot{\theta} \operatorname{Cos}(\theta-\beta)}\right]
$$

In order to accurately account for the sign of the drag torque, Equation (8) must be multiplied by the fluid velocity divided by the absolute value of the fluid velocity, or $v_{F} /\left|v_{F}\right|$.

The disc moment of inertia $J$ in Equation (1) consists essentially of two parts: the moment of inertia of the disc due to its own mass and the added inertia due to immersion of the disc in a fluid. Thus,

$$
\mathrm{J}=\mathrm{J}_{\mathrm{D}}+\mathrm{J}_{\mathrm{A}}
$$

where $J_{D}$ is the moment of inertia of the disc, and $J_{A}$ is the added moment of inertia of the disc. Then, from Equation (1)

$$
\begin{aligned}
J \ddot{\theta} & =\left(\mathrm{J}_{\mathrm{D}}+\mathrm{J}_{\mathrm{A}}\right) \ddot{\theta}=\sum \mathrm{T} \\
& =\mathrm{T}_{\mathrm{S}}+\mathrm{T}_{\mathrm{w}}+\mathrm{T}_{\mathrm{D}} ;
\end{aligned}
$$




$$
\begin{aligned}
\ddot{\theta} & =\left\{-\mathrm{W}_{\mathrm{b}} \overline{\mathrm{r}} \sin \theta+\frac{\mathrm{V}_{\mathrm{F}}}{\mid \mathrm{V}_{\mathrm{F}}} \frac{\mathrm{KoA}}{144(2 \mathrm{~g})}\left\{\left[\mathrm{V}_{\mathrm{F}}-\frac{\mathrm{r}_{\mathrm{p}} \dot{\theta}}{12} \operatorname{Cos}(\theta-\beta)\right]^{2}\right.\right. \\
& \left.\left.\left.+\frac{\mathrm{r}_{\mathrm{p}} \dot{\theta}}{12} \sin (\theta-\beta)\right]^{2}\right\} \mathrm{r}_{\mathrm{p}} \operatorname{Cos}(\phi+\beta)-\mathrm{k}_{\mathrm{s}}\left(\theta-\theta_{\mathrm{I}}\right)\right\} /\left(\mathrm{J}_{\mathrm{D}}+\mathrm{J}_{\mathrm{A}}\right) .
\end{aligned}
$$

All of the above variables necessary for the solution of the equation (except velocity as a function of time, and the drag coefficient and added inertia as functions of disc position) are easily determinable from the design drawings of the valve.

Statistical studies have shown that the mass of the disc has only a minor effect on the dynamics of the check valve in comparison with the importance of other parameters such as the flow transient and radial distances to the center of area and center of mass. Therefore, since the added moment of inertia of the disc due to its presence in a fluid is a result of an apparent increase in mass or "virtual mass," a large error in predicting or measuring the added moment of inertia of the disc has only a very small effect; for many valves this effect may be assumed to be negligible.

There are numerous methods available for predicting the flow transient; it is assumed the programer will have one of these methods already chosen.

The drag coefficient may be determined from simple steady-state tests on the check valve and use of Equation (10) with the velocity and acceleration of the disc equal to zero. However, since it is often not feasible to perform these tests, some estimate of the drag coefficient must be made. Again, statistical studies have shown that fairly large errors in the drag coefficient have minor effects on the pressure surge from the check valve slam, although disc position as a function of time may vary widely. The values for the drag coefficient as a function of the relative disc face angle given for Card 11 of Section IV, Program (Code) Input, are average values for numerous valves. Deviations of the drag coefficient by plus or minus half a decade for a given face angle have a negligible effect on the final results of the program.

For an iterative solution of the differential equation (Equation 10), two additional equations for $\dot{\theta}$ and $\theta$ are required. These are

$$
\theta_{\mathrm{t}+\mathrm{dt}}=\frac{(\mathrm{dt})^{2}}{6}\left(\ddot{\theta}_{\mathrm{t}+\mathrm{dt}}+2 \ddot{\theta}_{\mathrm{t}}\right)+\mathrm{dt} \dot{\theta}_{\mathrm{t}}+\theta_{\mathrm{t}}
$$

and

$$
\dot{\theta}_{\mathrm{t}+\mathrm{dt}}=\frac{\mathrm{dt}}{2}\left(\ddot{\theta}_{\mathrm{t}+\mathrm{dt}}+\ddot{\theta}_{\mathrm{t}}\right)+\dot{\theta}_{\mathrm{t}}
$$

where $d t$ is the finite difference increment, the subscript, $t$ is the beginning of the finite difference increment, and $t+d t$ is the end of the finite difference increment. 
In finite difference form the acceleration equation is

$$
\begin{aligned}
& \ddot{\theta}_{\mathrm{t}+\mathrm{dt}}=\left\{-\mathrm{w}_{\mathrm{b}} \overline{\mathrm{r}} \sin \theta_{\mathrm{t}+\mathrm{dt}}+\left(\left[\mid \mathrm{V}_{\mathrm{F}}-\frac{\left.\dot{\theta}_{\mathrm{t}+\mathrm{dt}} \mathrm{r}_{\mathrm{p}} \operatorname{Cos}\left(\theta_{\mathrm{t}+\mathrm{dt}}-\beta\right)\right]^{2}}{12}\right]^{2}\right) \mathrm{r}_{\mathrm{p}} \mathrm{KA}\right. \\
&+\left[\frac{\mathrm{r}_{\mathrm{p}} \dot{\theta}_{\mathrm{t}+\mathrm{dt}}}{12} \operatorname{Sin}\left(\theta_{\mathrm{t}+\mathrm{dt}}-\beta\right)\right]_{\mathrm{T}} \operatorname{Cos}(\phi+\beta) \frac{\mathrm{V}_{\mathrm{F}}}{\left|\mathrm{V}_{\mathrm{F}}\right|} \\
&\left.-\mathrm{k}_{\mathrm{s}}\left(\theta_{\mathrm{t}+\mathrm{dt}}-\theta_{\mathrm{I}}\right)\right\} /\left(\mathrm{J}_{\mathrm{D}}+\mathrm{J}_{\mathrm{A}}\right),
\end{aligned}
$$

with both $\mathrm{J}_{\mathrm{A}}$ and $\mathrm{K}$ evaluated at $\theta_{\mathrm{t}}$.

\section{B. Articulated and Linear Type Valves}

For an articulated or doubly pivoted check valve (Figures $3 \mathrm{~A}$ and $3 \mathrm{~B}$ ), these equations are also valid provided that the assumption is made that the disc pivots about only one pivot at a time. In other words, the disc rotates about a given pivot from the fully open position to an intermediate position between the fully open position and the seated position. At this point the disc ceases to rotate about the original pivot and rotates instead about a different pivot until the disc is seated. Where the pivot point changes the angle measured from the vertical line down from the pivot point to the line connecting the pivot point and the center of gravity of the disc is called the angle of articulation. Thus, with proper values assigned to the parameters the above equations are valid for each range of rotation.

For a check valve with a linear motion disc the equations require modification and redefinition of the parameters. Thus,

$\theta=$ Linear displacement of the disc from the seat (inches)

$\stackrel{\dot{\theta}}{=}$ Linear velocity of the disc (in./sec)

$\ddot{\theta}=$ Linear acceleration of the $\operatorname{disc}\left(\mathrm{in} . / \mathrm{sec}^{2}\right.$ )

$\theta_{\mathrm{I}}=$ Initial linear spring displacement (inches)

$\mathrm{k}_{\mathrm{s}}=$ Linear spring constant (lb/in.)

$\mathrm{W}_{\mathrm{b}}=$ Bouyant weight component parallel to the axis of motion (pounds)

$J_{D}=$ Mass of the disc $\left(1 \mathrm{~b} \mathrm{sec} /\right.$ in $\left.^{2}\right)$

$\mathrm{J}_{\mathrm{A}}=$ Added mass of the disc due to its immersion in fluid (lb $\mathrm{sec}^{2} / \mathrm{in}$.) Then,

$$
\ddot{\theta}_{t+d t}=\frac{-W_{b}+\left|V-\frac{\dot{\theta}_{t+d t}}{12}\right|\left(V-\frac{\dot{\theta}_{t+d t}}{12}\right) \frac{K \rho A}{9273.6}-k_{s}\left(\theta_{t+d t}-\theta_{I}\right)}{J_{D}+J_{A}} .
$$

\section{Method of Solution by the SLAM Code}

These equations are solved by the SLAM Code (MO188) written in FOR TRAN for the Philco-2000 computer. The method of solution is to assume that the values of displacement, velocity, and acceleration at the end of the time increment are the same as at the beginning. The displacement at the end of the time 


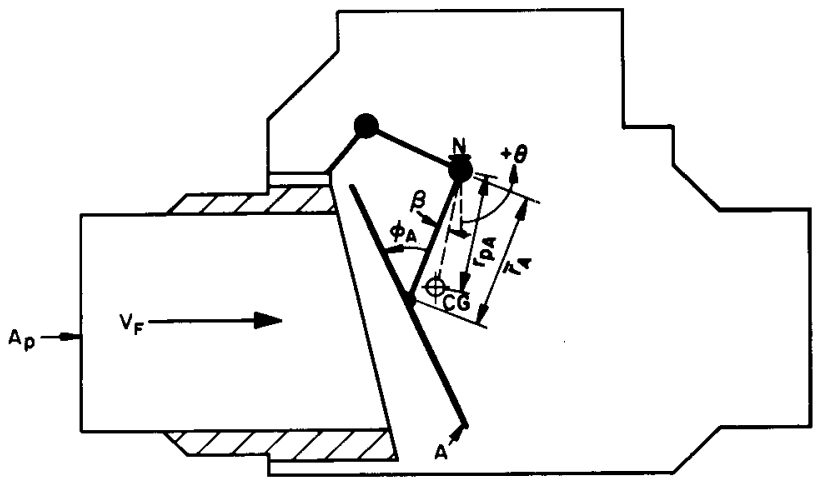

Figure 3A. Articulated Check Valve Showing Disc Rotating about Pivot Point N.

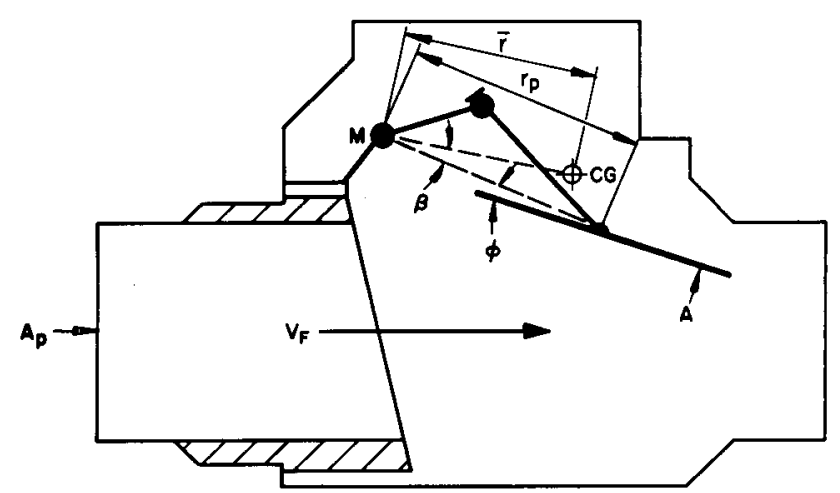

Figure 3B. Articulated Check Valve Showing Disc Rotating about Pivot Point $M$ after Articulation.

increment is determined from Equation (11). The velocity at the end of the time increment is determined from the new displacement and Equation (12). With this velocity and displacement the acceleration is determined at the end of the time step from Equation (13). The next time step is undertaken if the assumed and calculated accelerations are within a specified convergence criterion. If the accelerations are not within the specified convergence criterion, the velocity, acceleration, and displacement at the end of the time step are assumed equal to the values calculated and the calculation for the time step is repeated.

Appropriate tests for changing pivots, reaching the fully open or fully closed position, and reaching the time limit are performed after each time step.

At the completion of a closing transient the pressure surge is determined based on the assumption that the velocity goes instantaneously to zero at valve closure. The pressure surge is also calculated by the swept-out volume theorem for comparison. (This calculation requires the cross-sectional flow area of the pipe, Ap.)

\section{PROGRAM LIMITATIONS}

The limitations of the computer program are as follows:

1. The program will not predict repetitive check valve slam.

2. The program cannot accommodate a fluid velocity transient that passes through a maximum or minimum, but it can accommodate one that approaches or attains a steady-state condition.

3. The program can accept only steady-state initial conditions as input data.

\section{PROGRAM (CODE) INPUT}

The SLAM Code is designed to run successive problems, retaining in memory all input data from the previous problem and changing only those parameters for which input cards are supplied in the succeeding problem. Each input card is numbered to identify the input information; thus, the sequence of input cards may be in any order with the following three specific exceptions:

1. Cards 1,2, and 3 must always be in sequence and should be treated as a single card since their position in the problem deck does not matter, provided that the other specific exceptions are observed. If one of these three cards is present, all three must be present.

2. Card 23 must be the last card of that group of cards corresponding to a particular problem. 
3. Card 24 must be the last card of the input deck. In a sequence of problems only one 24 card will be present, and it must be the last card of the input deck.

NOTE: This does not eliminate the need for a blank card after each input deck required by some computer installations. This blank card is not considered part of the input deck.

The information on the various cards is shown symbolically in Figure 4 and is described below with an explanation of the symbols in parentheses.

Card 1 a. Column 10: Punch a 1.

Card 2 a. Column 10: Punch a 2.

b. Columns 11 to 70 inclusive: This space is available for any information the programer desires to place there. The limitation is that only those characters available on the key punch may be used. This information is reproduced at the top of each page of the problem output.

Card 3 a. Column 10: Punch a 3.

b. Columns 11 to 70 inclusive: Same as Card 2 .

GENERAL NOTE: The information in the following cards in columns 11 to 70 must contain a decimal in each 10-column spacing, but the information may be placed anywhere within the 10 columns.

Card 4 a. Column 10: Punch a 4.

b. Columns 11 to 20 inclusive: A blank or zero provides the standard output format with the output printed after each time step. The number 1 . provides the output after each ten time steps and after the final time step. The number 2. provides only the final conditions.

c. Columns 21 to 30 inclusive: A blank or zero provides an input edit. The number 1. eliminates the input edit.

d. Columns 31 to 40 inclusive: A blank or zero is used for a simple or singly-pivoted swingtype check valve. The number 1 , is used for an articulated or doubly pivoted check valve. The number 2 . is used for a check valve with a linear motion disc.

e. Columns 41 to 50 inclusive: A blank or zero indicates a closing transient. The number 1 . indicates an opening transient from the closed position. The number 2. indicates an opening transient from an intermediate position.

NOTE: If all options chosen are zero, this card may

be eliminated.

Card 5 a. Column 10: Punch a 5.

b. Columns 11 to 20: Fluid density (RHO)

c. Columns 21 to 30 : Initial fluid velocity (VIN)

$\left(\mathrm{lb} / \mathrm{ft}^{3}\right)$

$(\mathrm{ft} / \mathrm{sec})$

d. Columns 31 to 40 : Speed of sound in fluid (CSOUND)

(ft/sec)

e. Columns 41 to 50: Fluid velocity which would occur in the loop provided the check valve is not present; corresponds to the differential pressure necessary to hold the check valve closed and is required only for the opening transient (VMIN)

$(\mathrm{ft} / \mathrm{sec})$ 


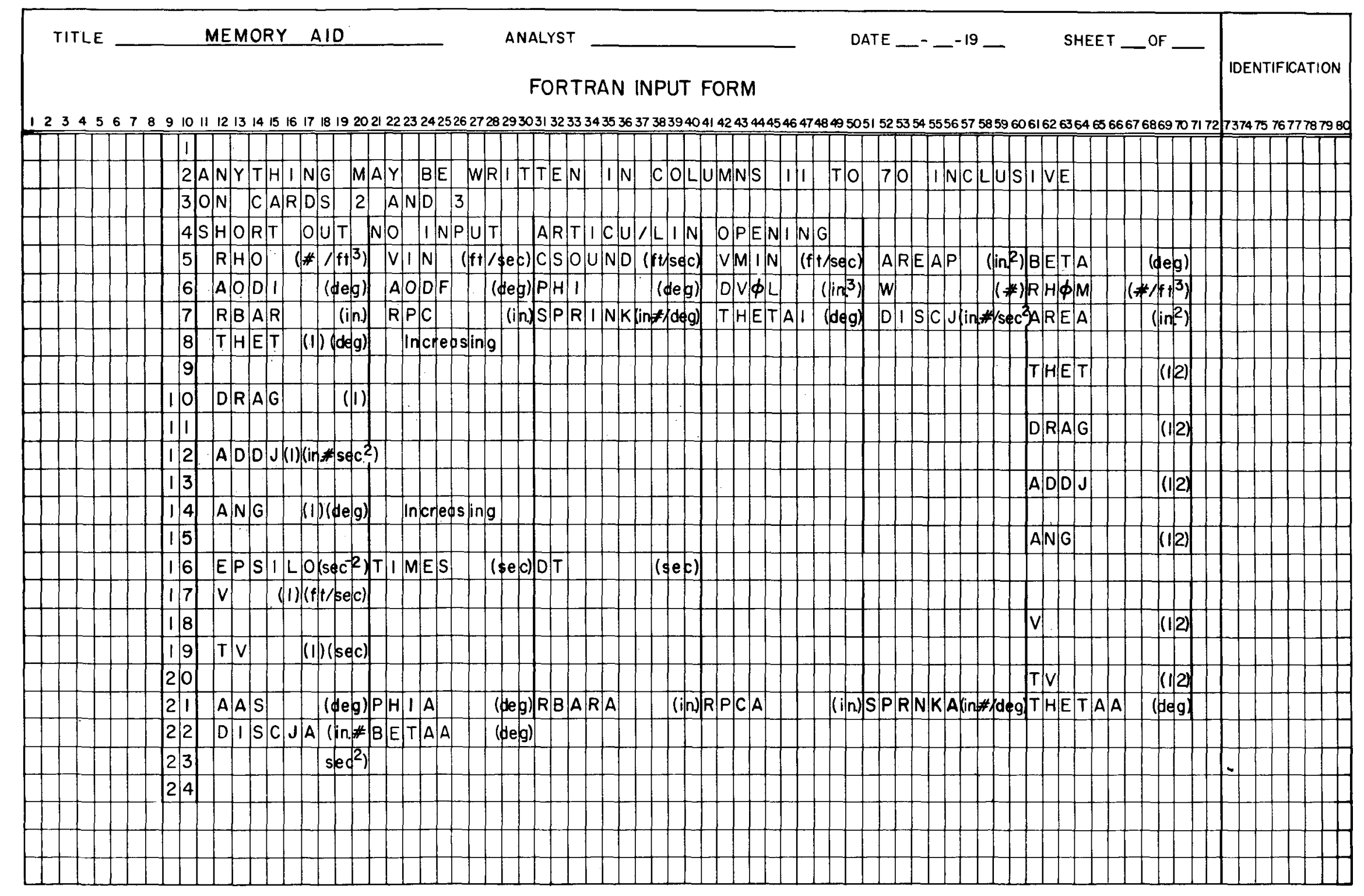

Figure 4. Memory Aid for Input. 
f. Columns 51 to 60 inclusive: Flow area of pipe (AREAP)

(in. ${ }^{2}$ )

g. Columns 61 to 70 inclusive: Singly Pivoted Valve - Angle between the line from the pivot point to the center of the disc face area and the line from the pivot point to the center of gravity. Angle is positive in the disc opening direction (BETA).

(degrees)

Articulated Valve - Angle is the same as for the singly pivoted valve but is in the range from articulation to the fully open disc position (BETA).

(degrees)

Card 6 a. Column 10: Punch a 6.

b. Columns 11 to 20 inclusive:

Pivoted Valve - Angle between the vertical line down from the pivot point and the line from the pivot point to the center of gravity when the disc is in the fully open position. Angle is positive in the opening direction. (AODI - A stands for Angle, OD stands for the zeroth derivative, and I stands for the initial position of the closing transient.)

Linear Motion Valve - Distance from the seated to the fully open disc position (AODI is still used).

(inches)

c. Columns 21 to 30 inclusive:

Pivoted Valve - Angle between the vertical line down from the pivot point and the line from the pivot point to the center of gravity with the disc in the fully closed position. Angle is positive in the disc opening direction (AODF - F for final position).

(degrees)

\section{Linear Motion Valve - blank}

d. Columns 31 to 40 inclusive:

Singly Pivoted Valve - Angle between the line from the pivot point to the center of gravity and the line through the plane of the disc face. Angle is positive in the same direction of rotation (clockwise or counterclockwise) as in $b$ and $c$ above (PHI).

Articulated Valve - Angle is the same as for the singly pivoted valve but is in the range from articulation to the fully open position (PHI). Linear Motion Valve - blank

e. Columns 41 to 50 inclusive: Volume of the disc (DV $\phi \mathrm{L}$ )

f. Columns 51 to 60 inclusive: Weight of the disc in air (W)

g. Columns 61 to 70 inclusive: Density of the disc metal ( $\mathrm{RH} \phi \mathrm{M})$ (pounds) $\left(\mathrm{lb} / \mathrm{ft}^{3}\right)$

NOTE: If $\mathrm{e}$. and $\mathrm{f}$. are both other than zero, $\mathrm{g}$. is ignored whether it is other than zero or not. If either e. or $\mathrm{f}$. is other than zero, $\mathrm{g}$. is used if it is other than zero, and the density of steel is used if $g$ 。 is zero.

Card 7 a. Column 10: Punch a 7.

b. Columns 11 to 20 :

Singly Pivoted Valve - Radial distance from the pivot to the center of gravity (RBAR).

(inches) 
Articulated Valve - Radial distance from the pivot to the center of gravity in the range from articulation to the fully open disc position

(RBAR).

(inches)

Linear Motion Valve - blank.

c. Columns 21 to 30 :

Singly Pivoted Valve - Radial distance from the pivot to the center of disc face area (RPC - Radius Pivot to the Center of area)

(inches)

Articulated Valve - Radial distance from the pivot to the center of the face area in the range from articulation to the fully open disc position (RPC)。

(inches)

NOTE: This information is required only if it is dif-

ferent from the information in $b$ above.

d. Columns 31 to 40 :

Singly Pivoted Valve - Spring constant (SPRINK).

(in. $\mathrm{lb} / \mathrm{deg}$ )

Articulated Valve - Spring constant for the range from articulation to the fully open position (SPRINK).

(in. $\mathrm{lb} / \mathrm{deg}$ )

Linear Motion Valve - Spring constant (SPRINK)

(lb/in.)

e. Columns 41 to 50 :

Singly Pivoted Valve - Preload spring displacement when the disc is on its seat (THETAI).

(degrees)

Articulated Valve - Preload spring displacement at the point of articulation for the range from articulation to the fully open position

(THETAI).

(degrees)

Linear Motion Valve - Preload spring displacement (THETAI).

(inches)

f. Columns 51 to 60 :

Singly Pivoted Valve - Moment of inertia of the disc (DISCJ). (in. $1 \mathrm{lb} \sec ^{2}$ )

Articulated Valve - Moment of inertia of the disc from articulation to the fully open position.

Linear Motion Valve - Mass of the disc.

g. Columns 61 to 70 inclusive: Disc face area (AREA). (in. $1 b \sec ^{2}$ ) (lb $\sec ^{2} / \mathrm{in}$.) (in. ${ }^{2}$ )

Card 8 a. Column 10: Punch an 8.

b. Columns 11 to 70 inclusive: Values of position (see Card 11).

Card 9 c. Column 10: Punch a 9.

d. Columns 11 to 70 inclusive: Values of position (see Card 11).

Card 10 a. Columns 9 and 10: Punch a 10.

b. Columns 11 to 70 inclusive: Values of the drag coefficient (see Card 11).

Card 11 c. Columns 9 and 10: Punch an 11.

d. Columns 11 to 17 inclusive: Values of the drag coefficient.

Cards 8,9, 10, and 11 provide space for table input of the drag coefficient as a function of position. Using a plot of the log of the drag coefficient versus position, there is sufficient space to represent this plot by up to eleven straight line segments. The disc positions (angle the disc face makes with the vertical, $\theta+\phi$, in degrees for pivoted motion valves and in inches for linear motion valves) corresponding to the 
points chosen are listed in decimal form in increasing value in succeeding ten-column spacings (without skipping any 10-column spacing), beginning with Column 11 on Card 8 and continuing to Column 70 , then to Column 11 on Card 9 and continuing to Column 70. If no data other than the 9 punch in Column 10 of Card 9 are contained on Card 9, this card may be eliminated. The dimensionless drag coefficients cor- ; responding to the data points chosen are listed on Cards 10 and 11 in the same position as on Cards 8 and 9. Again, Card 11 may be eliminated if it contains no information other than the 11 punch in Columns 9 and 10. For example, suppose the entire semilog plot may be represented between the points $(K=1500$, $\left.\theta=-30^{\circ}\right)$ and $\left(\mathrm{K}=0.0096, \theta=85^{\circ}\right)$. This information may be supplied by -30 . in Columns 11 to 20 of Card 8, 85. in Columns 21 to 30 of Card 8, 1500. in Columns 11 to 20 of Card 10, and 0.0096 in Columns 21 to 30 of Card 10, with Cards 9 and 11 eliminated. In the absence of more reliable data, these values may be used as an approximation of the drag coefficient for swing-type check valves 。 [ THET(I), I = 1, 12 and DRAG(I), I = 1, 12]

Card 12 a. Columns 9 and 10: Punch a 12.

b. Columns 11 to 70 : Values of added inertia (see Card 15).

Card 13 a. Columns 9 and 10: Punch a 13.

b. Columns 11 to 70 : Values of added inertia (see Card 15).

Card 14 a. Columns 9 and 10: Punch a 14.

b. Columns 11 to 70: Values of position (see Card 15).

Card 15 a. Columns 9 and 10: Punch a 15.

b. Columns 11 to 70 : Values of position.

Cards 12 to 15 inclusive contain the added moment of inertia (for pivoted valves) and added mass (for linear motion valves) of the disc resulting from its immersion in a fluid. The information is supplied in the same manner as the drag coefficient except that a linear plot is used rather than a semilog plot. The disc position in degrees for the pivoted valve and in inches for the linear motion valve is contained in increasing values on Cards 14 and 15, and the added inertia or mass is contained on Cards 12 and 13 . If the added inertia or mass is independent of position, this constant may be contained in Columns 11 to 20 of Card 12 and Cards 13, 14, and 15 are eliminated. [ADDJ(I), I = 1, 12 and ANG(I) I = 1, 12]

Card 16 a. Columns 9 and 10: Punch a 16.

b. Columns 11 to 20 inclusive: $\theta$ convergence criterion on acceleration. The difference between the assumed acceleration and calculated acceleration must be less than or equal to this value (EPSILO). $\left(\sec ^{-2}\right)$

c. Columns 21 to 30 inclusive: Maximum running time of the problem (TIMES).

d. Columns 31 to 40 inclusive: Finite difference increment (DT).

Card 17 a. Columns 9 and 10: Punch a 17.

b. Columns 11 to 70: Values of velocity (see Card 20).

Card 18 a. Columns 9 and 10: Punch an 18.

b. Columns 11 to 70: Values of velocity (see Card 20).

Card 19 a. Columns 9 and 10: Punch a 19.

b. Columns 11 to 70: Values of time (see Card 20).

Card 20 a. Columns 9 and 10: Punch a 20.

b. Columns 11 to 70 : Values of time. 
Cards $17,18,19$, and 20 are for the input of the flow transient as a function of time. This allows representation by up to eleven straight line segments of a linear plot of velocity versus time. The time in seconds is contained on Cards 19 and 20 in increasing values. The corresponding velocities in $\mathrm{ft} / \mathrm{sec}$ are on Cards 17 and 18. This information must be supplied as on Cards 8 to 11 inclusive. [V(I), I= 1, 12 and $\operatorname{TV}(\mathrm{I}), \mathrm{I}=1,12]$

Card 21 This card is required only for an articulated valve.

a. Columns 9 and 10: Punch a 21 .

b. Columns 11 to 20 inclusive: Angle between the vertical line down from the pivot point and the line from the pivot point to the center of gravity when the pivot about which the disc rotates is in the range nearest the closed position (AAS - Angle at which Articulation S

(degrees)

c. Columns 21 to 30 inclusive: Angle between the line from the pivot point to the center of gravity of the disc and the line through the plane of the disc face. Angle is in the range from articulation to the fully seated position (PHIA: PHI Articulated).

(degrees)

d. Columns 31 to 40 inclusive: Radial distance from the pivot point to the center of gravity between articulation and the fully seated position (RBARA - RBAR Articulated). (inches)

e. Columns 41 to 50 inclusive: Radial distance from the pivot point to the center of the disc face area when the disc is in the range between articulation and the fully seated position (RPCA).

(inches)

NOTE: This information is required only if different from d above.

f. Columns 51 to 60 inclusive: Spring constant in the same range as above (SPRNKA).

g. Columns 61 to 70 inclusive: Initial spring displacement in the same range as above (THETAA).

Card 22 This card is required only for an articulated valve.

a. Columns 9 and 10: Punch a 22 .

b. Columns 11 to 20 inclusive: Disc moment of inertia in the same range as for Card 21 (DISCJA).

c. Columns 21 to 30 inclusive: Angle between the line from the pivot point to the center of the disc face area and the line from the pivot point to the center of gravity. Angle is positive in the disc opening direction in the same range as for Card 21 (BE TAA).

(degrees)

Card 23 a. Columns 9 and 10: Punch a 23.

Card 24. a. Columns 9 and 10: Punch a 24.

The minimum cards required for the first problem in a sequence are as follows:

1. Single Pivot - Cards 5, 6, 7, 8, 10, 12, 16, 17, 19, and 23.

2. Articulated - Same as Single Pivot plus Cards 4, 21, and 22.

3. Linear - Cards $4,5,6,7,8,10,12,16,17,19$, and 23. 
Additional cards may be required, and Cards 1,2 , and 3 should be included for problem identification.

The second problem in the sequence should contain at least one data card and a Card 23. However, Cards 1,2 , and 3 should be included with the problem identification for later convenience.

The last problem in the sequence must contain a 24 Card.

Columns 1 to 8 inclusive and Columns 71 to 80 inclusive on all cards may contain any information the programer may desire. These columns are ignored by the code and have no effect whatsoever.

V. TERMINOLOGY

\section{Symbol}

A

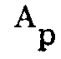

$\beta$

$\chi$

D

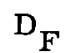

dt

$\eta$

g

$\overrightarrow{\mathrm{i}}$

$\overrightarrow{\mathrm{j}}$

J

$\mathrm{J}_{\mathrm{A}}$

$\mathrm{J}_{\mathrm{D}}$

K

$\mathbf{k}$

$\phi$

$\overline{\mathbf{r}}$ $\underline{\text { Definition }}$

Area of the disc face

Area of the valve pipe

Angle measured from $r$ to $\bar{r}$, positive in the same direction as $\theta$

Angle between the relative velocity vector and the perpendicular to the disc face

Drag

Net drag force on the disc

Finite difference increment

Angle between the disc velocity vector and the $\mathrm{X}$-axis

Gravitational constant

Unit vector along the $\mathrm{X}$-axis

Unit vector along the $\mathrm{Y}$-axis

Disc moment of inertia

(1)* Added moment of inertia of the disc

(2)* Added mass of the disc

(1) Moment of inertia of the disc

(2) Mass of the disc

Drag coefficient

(1) Spring constant

(2) Spring constant

Angle measured from $\overline{\mathbf{r}}$ to the disc face, positive in the same direction as $\theta$

Radial distance from the pivot point to the center of gravity
Dimension

inches $^{2}$

inches $^{2}$

degrees

degrees

feet

pounds

seconds

degrees

$\mathrm{ft} / \mathrm{sec}^{2}$

1

1

in. $1 \mathrm{~b} \mathrm{sec}{ }^{2}$

in. $1 \mathrm{~b} \mathrm{sec}{ }^{2}$

$\mathrm{lb} \sec ^{2} /$ in.

in. $\mathrm{lb} \mathrm{sec}^{2}$

$1 \mathrm{~b} \mathrm{sec} 2 /$ in.

1

in. $1 \mathrm{~b} / \mathrm{rad}$

$\mathrm{lb} /$ in.

degrees

inches

*The (1) refers to the definition when applied to a swing disc check valve, and the (2) refers to the definition when applied to a linear motion disc check valve. 


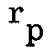

$\rho$

$\mathrm{T}$

$\mathrm{T}_{\mathrm{D}}$

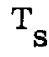

$\mathrm{T}_{\mathrm{w}}$

$\theta$

$\stackrel{1}{\theta}$

$\ddot{\theta}$

$\theta_{\mathrm{I}}$

$\overrightarrow{\mathrm{V}}_{\mathrm{D}}$

$\overrightarrow{\mathrm{V}}_{\mathrm{F}}$

$\mathrm{V}_{\mathrm{F}}$

$\overrightarrow{\mathrm{v}}_{\mathrm{R}}$

$\mathrm{v}_{\mathrm{R}}$

$\mathrm{w}_{\mathrm{b}}$

Subscripts

$\mathrm{t}$

$\mathrm{t}+\mathrm{dt}$
Radial distance from the pivot point to the center of disc face area

Density of the fluid

Torque

Torque on the disc due to the viscosity of the fluid

Spring torque

Weight torque

(1) Angular displacement of the disc from the vertical line down from the pivot point; angle is positive in the disc opening direction.

(2) Displacement of the disc from the fully closed position

(1) Angular velocity of the disc

(2) Linear velocity of the disc

(1) Angular acceleration of the disc

(2) Linear acceleration of the disc

(1) Initial angular spring displacement

(2) Initial linear spring displacement

Vector velocity of the disc

Vector velocity of the fluid

Magnitude of the fluid velocity $=\left|\vec{V}_{F}\right|$

Vector velocity of the disc velocity vector relative to the fluid velocity vector

Magnitude of the disc velocity relative to the fluid velocity

(1) Buoyant weight of the disc

(2) Buoyant weight component of the disc parallel to the axis of disc motion inches

$\mathrm{lb} / \mathrm{ft}^{3}$

in. $\mathrm{lb}$

in. $1 b$

in. $1 b$

in. $1 b$

radians

inches

$\mathrm{rad} / \mathrm{sec}$

in./sec

$\mathrm{rad} / \mathrm{sec}^{2}$

in. $/ \sec ^{2}$

degrees

inches

$\mathrm{ft} / \mathrm{sec}$

$\mathrm{ft} / \mathrm{sec}$

$\mathrm{ft} / \mathrm{sec}$

$\mathrm{ft} / \mathrm{sec}$

$\mathrm{ft} / \mathrm{sec}$

pounds

pounds

Beginning of the time step

End of the time step 
I OUNI TSFDT I, 8 T, 12, 10,22, BUFERI-DTO,10T, , ,22, BUFER2, BUFER3\$ DIMENSION CARD (10), CARDO (10), ANG(12), DRAG (12), THET (12), VEL (12), TV $1(12)$, STORE (12), ADDJ $(12)$ GO TO 557

102 STOP

2 FORMAT $(10 X, 10 A 6,2 X)$

3 FORMAT $(8 X$, I $2,6 F 10.5)$

4 FORMAT $(1 \mathrm{H1}, 25 \mathrm{X}, 52 \mathrm{HSLAM}$ CODE MO188 CHECK VALVE SLAM PRESSURE S IURGE.,25X,6:HPAGE , I 3 )

5 FORMAT (1HQ, 1OA6)

-6 FORMAT $195 \mathrm{HD}$ THERE IS AN INCORRECT INPUT CARD SEQUENCE. THIS PROB ILEM DID NOT RUN.

7 FORMAT $(8 X, 12)$

8 FORNAT (1HC, $5 \mathrm{X}, 12 \mathrm{HINPUT}$ EDIT.)

10 FORMAT (36HOTHE FOLLOHING PROBLEMS DID NOT RUN.)

11 FORMAT (1H 1OA6)

12 FORMAT (43HUDENSITY OF FLUID 1 INITIAL FLUID VELOCITY

14 FCRMAT $143 \mathrm{H}$ SPEED OF SOUND $(F T / S E C)=F 13.4)$ IFULL OPEN ANGLE FROM VERTICAL $\quad(D E G)=F 13.4)$

15 FORMAT $143 \mathrm{H}$ FULL CLOSED ANGLF FROM VERTICAL (DEG)=F13.4,4X,42H IDISC FACE ANGLE

$(D E G)=F 13.4)$

16 FORMAT (43H FINITE DIFFERENCE INCREMENT
1 PIPE AREA
(IN SQ) $=F 13.4)$

17 FORMAT $143 \mathrm{H}$ PIVOT TO CG ARM IPIVOT TO CENTER OF AREA

18 FORMAT $143 \mathrm{H}$ SPRING CONSTANT IINITIAL SPRING DISPLACEMENT

19 FORMAT 143H DISC INERTIA IDISC FACE AREA

20 FORMAT 143 H CONVERGENCE CRITERION IMAXI:AUM INTEGRATION TIME $(\mathrm{SEC})=\mathrm{F} 13 \cdot 4,4 \times, 42 \mathrm{H}$ $(I N)=F 13.4)$

$(\mathrm{IN})=\mathrm{F} 13 \cdot 4,4 \mathrm{X}, 42 \mathrm{H}$ (IN-LBS/DEG) $=F 13.4,4 X, 42 \mathrm{H}$ $(D E G)=F 13 \cdot 4)$

( IN-LB-SEC SQ) $=F 13 \cdot 4,4 X, 42 \mathrm{H}$

21 FORMAT (1HC, $18 X, 4 H D R A G, 31 X, 13$ HADDED INERT IA, 33X,5HWATER)

22 FORVAT (1H, 14X,11HCOEFFICIENT, $28 X, 12$ HDUE TO WATER, 32X, 8HVELOCITY)

23 FORHAT (1H, 8X, 5HANGLE, 16X, 5HVALUE, 15X, 5HANGLE, 16X, 5HVALUE, 15X, 5HT IIME, I $4 X, 8$ HVELOCITY

24 FORIVAT $(1 \mathrm{H})$

25 FORMAT (IH, F $15.4,5 F 20.4$ )

26 FORMAT (IOHO OUTPUT)

28 FORVIAT IIHC,9X, 9HANGLE OF, $4 \mathrm{X}, 8 \mathrm{H}$ DISC, $5 \mathrm{X}, 10 \mathrm{H}$ DISC, $6 \mathrm{X}, 10 \mathrm{H}$ 


\section{WEIGHT $, 5 X, 10 \mathrm{H}$ FLOW $, 5 \mathrm{X}, 10 \mathrm{H}$ SPRING $, 5 \mathrm{X}, 10 \mathrm{H} \quad$ INERTIA $, 5 \mathrm{X}, 9 \mathrm{H}$ 2 WATER I}

29 FORMAT $15 \mathrm{H}$ TIME, $5 \mathrm{X}, 9 \mathrm{H}$. DISC ,5X,8HANGULAR, $5 X, 10 \mathrm{H}$ ANGULAR ,5X, 1 $10 \mathrm{H}$ MOMENT, $5 \mathrm{X}, 10 \mathrm{H}$ MOMENT, $5 \mathrm{X}, 10 \mathrm{H}$ MOMENT, $5 \mathrm{X}, 10 \mathrm{OH}$ MOMENT, $5 \mathrm{X}$ 2 , 9H VELOCITY)

30 FORMAT (1H,9X, 9HFROM VERT, 5X, 8HVELOCITY,5X, $10 H$ ACCELER.

31 FORMAT ( $6 H$ (SEC), 4X, 9H(DEGREES), $5 X, 9 H(R A D / S E C), 3 X, 12 H(R A D / S E C S Q)$, $15 X, 8 H(I N-L B S), 7 X, 8 H(I N-L B S), 7 X, 8 H(I N-L B S), 8 X, 8 H(I N-L B S), 6 X, 8 H(F T / S$ 2E(I)

32 FORMAT (1H,F5.3, 2F13.4,5F15.4,F14.4)

33 FORMAT $(I H / 1 / 101 H$ THE CONDITIONS OF THE CALCULATIONS EXCEEDED TH $1 E$ VALUES OF THE INPUT TABLES FOR THE DRAG COEFFICIENT •

34 FORMAT 124 HOTHE INITIAL VALVE ANGLE,54X,7H(DEG) =F12.4)

35 FORMAT $185 \mathrm{H}$ THE EXTINGUISHED VELOCITY BASED ON THE EQUATIONS OF MO ITION (FT/SEC) =F12.4)

36 FORMAT $(85 H$ THE DELTA P CORRESPONDING TO THIS EXTIGUISHED VELOCITY (PSI) =F 12.4)

37 FORMAT $(85 H$ THE EXTINGUISHED VELOCITY BASED ON THE SWEPT OUT VOLUM 1E THEORY (FT/SEC) =F12.4)

38 FORMAT 15 HHITHIS PROBLEM EXCEEDED THE SPECIFIED TIME LIMIT OF, 1. F3.1, 1OH SECONDS. ।

39 FORMAT $143 \mathrm{H}$ DISC VOLUME 1 WEIGHT OF OISC

40 FORMAT $143 \mathrm{H}$ DISC VOLUME IDENSITY OF DISC METAL

41 FORMAT $143 \mathrm{H}$ WEIGHT OF DISC IDENSITY OF DISC METAL

42 FORMAT (43H DISC ANGLE FOR PIVOT CHANGE (DEG) $=F 13.4,4 \times, 42 \mathrm{H}$ IDISC FACE ANGLE AFTER PIVOT CHANGE (DEG)=F13.4)

43 FORMAT $(43 \mathrm{H}$ PIVOT TO CG ARM AFTER PIVOT CHANGE $($ IN $)=F 13.4,4 \mathrm{X}, 42 \mathrm{H}$ IPIVOT TO CENTER OF AREA AFTER CHANGE (IN)=F 13.4 )

44 FORMAT (43H SPRING CONSTANT AFTER CHANGE (IN-LBS/DEG) $=$ F $13.4,4 \mathrm{X}, 42 \mathrm{H}$ 1 IN SPRING DISPLACE AFTER CHANGE (DEG) =F13.4)

45 FORWIAT ( 43 H DISC INERTIA AFTER CHANGE (IN-LB-SEC SQ) $=F 13.4,4 X, 42 H$ IF INITE DIFFERENCE INCREMENT (SEC) $=F 13.4$ )

46 FORMAT IIH //1 $97 \mathrm{H}$ THE CONDITIONS OF THE CALCULATIONS EXCEEDED TH IE VALUES OF THE INPUT TABLES FOR VELOCITY VS TIME.)

47 FORMAT (IH / / $93 \mathrm{H}$ THE CONDITIONS OF THE CALCULATIONS EXCEEDED TH IE VALUES OF THE INPUT VALUES AT STATEMENT 242.1

48 FORMAT $11 \mathrm{H} / / / 178 \mathrm{H}$ THE CONDITIONS OF THE CALCULATIONS EXCEEDED TH IE VALUES OF THE INPUT VALUES FOR THE ADDED MOMENT OF INERTIA•I

49 FORMAT (IH /// 93H THE CONDITIONS OF THE CALCULATIONS EXCEEDED TH IE VALUES OF THE INPUT VALUES AT STATEMENT 281.

50 FORMAT 1 IH // $93 \mathrm{H}$ THE CONDITIONS OF THE CALCULATIONS EXCEEDED TH 
IE VALUES OF THE INPUT VALUES AT STATEMENT 138.1

51. FORMAT I 57HOTHE ARTICULATED VALVE HAS CHANGED PIVOTS AT THIS POIN $1 T \cdot / / / 1$

52 FORNIAT ( IH /// $104 \mathrm{H}$ THE INITIAL VELOCITY IS SUFFICIENT TO CLOSE ITHE VALVE. THUS THE TRANSIENT IS FROM THE CLOSED POSITION.)

53 FORMAT $(1 \mathrm{H} / 1 / 93 \mathrm{H}$ THE CONDITIONS OF THE CALCULATIONS EXCEEDED TH IE VALUES OF THE INPUT TABLES AT STATEMENT 297.1

54 FORMAT IIH /// 93 H THE CONDITIONS OF THE CALCULATIONS EXCEEDED IH IE VALUES OF THE INPUT TABLES AT STATENENT 300.:

55 FORMAT ( $1 \mathrm{H} / / / 2 O H$ THE VALVE IS OPEN.)

56 FORMAT $143 \mathrm{H}$ VELOCITY TO HOLD DISC SEATED

57 FORMAT $143 \mathrm{H}$ SPEED OF SOUND IFULL OPEN POSITION

58 FORMAT $143 \mathrm{H}$ - SPRING CONSTAN, IINITIAL SPRING DISPLACEMENT

59 FORMAT 143 H CROSS-SECTIONAL AREA

IFINITE DIFFERENCE INCREMENT

$(\mathrm{IN})=\mathrm{F} 13 \cdot 4)$

$(F T / S E C)=F 13.4)$

$(\mathrm{FT} / \mathrm{SEC})=\mathrm{F} 13.4,4 \mathrm{X}, 47 \mathrm{H}$

( IN $=F 13.4)$

$($ LBS $/ I N)=F 13 \cdot 4,4 X, 42 \mathrm{H}$

$(S E C)=F 13.4$ )

$(\mathrm{IN}-\mathrm{SQ})=\mathrm{F} 13.4,4 \mathrm{X}, 42 \mathrm{H}$

60 FORMAT (IH , 7X,8HPOSITION., 14X, 5HVALUE, 13X,8HPOS ITION, 13X, 5HVALUE, $116 X, 4 \mathrm{HT}$ IME, $13 \mathrm{X}, 8 \mathrm{HVELOCITY})$

61 FORMAT $15 \mathrm{H}$ TIME, $6 \mathrm{X}, 8 \mathrm{H}$ DISC, $5 \mathrm{X}, 8 \mathrm{H}$ DISC, $5 \mathrm{X}, 10 \mathrm{H}$ DISC, $5 \mathrm{X}$, $110 \mathrm{H}$ FLOW ,5X,IOH SPRING ,5X,10H INERTIA, $5 \mathrm{X}, 9 \mathrm{H}$ WATER,

62 FORMAT (IH, 9X, 9H POSITION, 5X,8HVELOCITY, 5X,10H ACCELER., $5 X$, $110 \mathrm{H}$ FORCE, $5 X, 10 \mathrm{H}$ FORCE, $5 X, 1 \mathrm{OH}$ FORCE, $5 \mathrm{X}, 9 \mathrm{H}$ VELOCITY

63 FORMAT (6H (SEC), 5X, 8H(INCHES), $\mathrm{XX}, 8 \mathrm{H}(\mathrm{IN} / \mathrm{SEC}), 5 \mathrm{X}, 1 \mathrm{IH}(\mathrm{IN} / \mathrm{SEC}$ SQ), $4 \mathrm{X}$, $110 \mathrm{H}$ (POUNDS), $5 \mathrm{X}, 1 \mathrm{OH}$ (POUNDS), $5 \times, 10 \mathrm{H}$ (POUNDS), $5 \mathrm{X}, 9 \mathrm{H}$ (FT/SEC),

64 FORMAT $11 \mathrm{H} / / / 93 \mathrm{H}$ THE CONDITIONS OF THE CALCULATIONS EXCEEDED THE 1 VALUES OF THE INPUT TABLES AT STATEMENT 338.1

65 FORMAT $(1 \mathrm{H}, \mathrm{F} 5.3, \quad 2 \mathrm{~F} 13.4,4 \mathrm{~F} 15.4, \mathrm{~F} 14.4)$

66 FORMAT $(43 \mathrm{H}$ CONVERGENCE CRITERION (INCHES) $=$ F $13.4,4 \mathrm{X}, 42 \mathrm{H}$ IMAXIMUM INTEGRAT ION TIME (SÉC) $=$ F13.4)

67 FORMAT (IHO,23H. THE OPTIONS CHOSEN ARE / $11 \mathrm{H}$ OPTION $1=13,7 \mathrm{X}$, 11 OHOPTION $2=13,7 \mathrm{X}, 1$ IOHOPTION $3=13,7 \mathrm{X}, 10$ HOPTION $4=13$ )

68 FORMAT (27HOTHE INITIAL VALVE POSITION, 48X,9H(INCHES) =F 12.4 )

69 FORMAT 1 IH /// 69H THE FINITE DIFFERENCE INCREMENT CHOSEN FOR TH IIS PROBLEM IS TOO LARGE,

$261 \mathrm{H}$ FOR CONVERGENCE. IT HAS BEEN DECREASED BY A FACTOR OF 10 TO F5 $3.4,9 H$ SECONDS. $1 / 1$,

70 FORNAT $11 \mathrm{H} / / / 69 \mathrm{H}$ THE DECREASED FINITE DIFFERENCE INCREMENT HAS 1 NOT BEEN SUFFICIENT TO / 69H PROMOTE CONVERSION AFTER 500 ITERA $2 T$ IONS. IT IS RECOMENDED THAT THE, 69H INPUT DATA BE REVIEWED AN 3D. IF NO INPUT ERRORS ARE DETECTED THAT THE / 6.2H PROBLEM BE RESUBM 4ITTED WITH A SMALLER FINITE DIFFERENCE INCREMGNT:

71 FORMAT 1 IH $/ 1 / 69 \mathrm{H}$ THE ART ICULATED VALVE REQUISRES A MUCH SMALLER IFINITE DIFFERENCE ' / 69H INCREMENT BETWEEN THE CLOSED POSITIO 
$2 N$ AND THE POSITION FOR

I $69 H$ ARTICULATION THAN AFTER 3ART ICULATION. THEREFORE, DURING THE FORMER, /69H INTERVAL, THE S 4PECIFIED INCREMENT IS REDUCED BY A FACTOR OF 10.

72 FORMAT $143 \mathrm{H}$ PIPE AREA

(IN SQ) $=F 13 \cdot 4 i$

73 FORMAT $(2 \mathrm{HI}, 10 \mathrm{X}, 82 \mathrm{HSLAM}$ CODE MO188 CHECK VALVE SLAM PRESSURE 5 IURGE. COMPILFD OCTOBER 1962 .

74 FORMAT ( 85 H ANGLE BETWEEN LINES FROM PIVOT TO CG AND CENTER OF AR IEA $(D E G)=F I 3 \cdot 4)$

75 FORMAT $(85 \mathrm{H}$ ANGLE BETWEEN LINES FROM PIVOT TO CG AND CENTER OF AR $1 E A$ AFTER PIVOT CHANGE

557 WRITE OUTPUT TAPE 10,73

100 READ INPUT TAPE $8,3,11,(S T O R E(I 2), 12=1,6)$

C

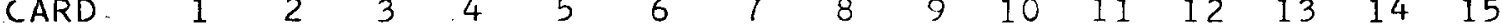
GO TO $(101,142,142,206,151,152,153,154,156,158,160,162,164,166,168$ $1,170,171,173,175,177,255,263$, $179,1021,11$

$\mathrm{C}$ $\begin{array}{lllllllll}16 & 17 & 18 & 19 & 20 & 21 & 22 & 23 & 24\end{array}$

THE PRECEDING TWO STATEMEN READ 'AND STORE INPUT DATA

206 JUMP $1=$ STORE $(1)$

C A 1. IN COLUMNS $11-20$ CAUSES PRINT OUT AT EVERY TENTH TIME INCREMENT. A 2. ELIMINATES ALL INTERMEDIATE DATA. JUMP2 = STORE (2)

C. A 1. IN COLUMNS 21-30 ELIMINATES THE INPUT EDIT. JUMP3 = STORE (3)

A 1. IN COLUMNS 31-40 INDICATES AN ARTICULATED VALVE.

C A 2. IN CCLUMNS $31-40$ INDICATES A LINEAR MOTION VALVE. JUMP4 = STORE (4)

A 1. IN COLUMNS 41-50 INDICATES AN OPENING TRANSIENT FROM CLOSED POSITICN AND A.2. INDICATES AN OPENING TRANSIENT FROM SOME INTERMEDIATE ANGLE

JUMPS = STORE (5)

JUMPG = STORE $(6)$

GO TO 100

$101 \mathrm{I} 3=1$

READ INPUT TAPE 8,2, CARD, CARDO

GO TO 100

142 JUMP $=1$

WRITE OUTPUT TAPE 10,6

C FOR ANY PROBLEM, CARDS 1,2 AND 3 MUST BE IN .SEQUENCE. IF NOT IN

$C$ SEQUENCE, THE PROBLEM AND ALL OTHERS PRECEDINÓ A 24 CARD ARE NOT PERFORMED.

$I 10=110+2$

143 READ INPUT TAPE $8,7,11$

IF (II-1) 102,144,145

145 IF $($ I $1-22), 143,102,102$ 
144 READ INPUT TAPE 8,2, , CARD, CARDO

IF (55-I10) 148,147,147

$14813=13+1$

WRITE OUTPUT TAPE $10,4,13$

I $10=2$

147 GO TO $(149,150)$, JUMP

149 WRITE OUTPUT TAPE 10,10

150 WRITE OUTPUT TAPE 10,5 , CARD WRITE OUTPUT TAPE 10,5, CARDO

$110=110+5$

$J U M P=2$

GO. TO 143

151 RHO = STORE (1)

VIN $=$ STORE (2)

CSOUND = STORE (3)

VMIN = STORE $(4)$

AREAP = STORE $(5)$

BETA = STORE (6)

C THIS SEQUENCE STORES CATA ON CARD 5. GO TO 100

$152 \mathrm{ACDI}=$ STORE $(1)$

AODF = STORE (2)

PHI = STORE (3)

DVOL = STORE $(4)$

$W \quad=$ STORE $(5)$

RHOM = STORE (6)

C THIS SEQUENCE STORES DATA ON CARD 6. GO TO 100

153 RBAR =STORE (I)

IF ( STORE (2)) $253,252,253$

$252 \mathrm{RPC}=$ STORE $(1)$

GO TO 254

$253 \mathrm{RPC}=$ STORE (2)

254 SPRINK = STORE (3)

THETAI = STORE (4)

DISCJ $=S T O R E(5)$

AREA = STORE (6)

$c$

THIS SEQUENCE STORES DATA ON CARD 7. GO TO 100

$15400 \quad 155$ II $1=1,6$

155 THET (III) = STORE (III)

c

THIS SEQUENCE STORES DATA ON CARD 8. GO TOICO

156 DO 157 I $11=1,6$ 
157 THET $(111+6)=$ STORE $(I 11)$

$C$ THIS SEQUENCE STTORES DATA ON CARD 9. GO TO 100

158 DO 159 III $=1,6$

159 DRAG (III) = STORE (I II)

C

THIS SEQUENCE STORES DATA ON CARD 10. GO TO 100

160 DO 161 III $=1,6$

161 DRAG (III+6) = STORE (III)

C THIS SEQUENCE STORES DATA ON CARD 11. GO TO 100

162 DO 163 III $=1,6$

163 ADDJ (II1) = STORE (I I1)

c THIS SEQUENCE STORES DATA ON CARD 12. GO TO 100

164 DO 165 I $11=1,6$

165 ADDJ $(I 11+6)=$ STORE (I II)

C THIS SEQUENCE STORES DATA ON CARD 13. GO TO 100

166 DO. 167 III $=1,6$

167 ANG(III) = STORE (III)

C THIS SEQUENCE STORES DATA ON CARD 14. GO TO 100

168 DO 169 I $11=1,6$

169 ANG (III+6) = STORE (III)

C THIS SEQUENCE STORES DATA ON CARD 15. GO TO 100

170 EPSILO = STORE (1.)

TIMES $=$ STORE $(2)$

QT =STORE (3)

C THIS SEQUENCE STORES DATA ON CARD 16. GO TO 100

171 DO 172 III $=1,6$

172 VELIIII) = STORE (III)

$C$ THIS SEQUENCE STORES DATA ON CARD 17. GO TO 100

173 DO 174 III $=1,6$

174 VEL $(I 11+6)=$ STORE $(I 11)$

C THIS SEQUENCE STORES DATA ON CARD 18. GO TO 100

$17500 \quad 176 \quad I 11=1,6$

176 TVIII 1$)=$ STORE (III) 
177 DO 178 I $11=1,6-$

178 TV $(I I 1+6)=$ STORE (III)

THIS SEQUENCE STORES DATA ON CARD 20.

GO TO 100

255 AAS $=$ STORE (1)

PHIA = STORE (2)

RBARA = STORE (3)

IF ( STORE (4) $260,261,200$

261 RPCA = STORE (3)

GO TO 262

260 RPCA $=$ STORE (4)

262 SPRNKA $=$ STORE $(5)$

THETAA = STORE (6)

C THIS SEQUENCE STORES THE DATA ON CARD 21.

GO TO 100

263 DISCJA=STORE ( 1

BETAA: $=S T O R E(2)$

GO TO 100

C THIS SEQUENCE STORES THE DATA ON CARD 22.

179 JEST2 $=$ JUMP $2+1$

- RTEMI = RBAR

RTEM2 = RPC

$A T E M 2=B E T A$

PHITEM $=$ PHI

SKTEM = SPRINK

THETAT $=$ THETAI

DJTEM $=$ DISCJ

JEST $1=J U M P 1+1$

$121=0$

I $22=0$

$I 23=0$

JEST3 = JUMP3 + 1

JUMP $14=$ JEST 3

JEST $4=J U M P 4+1$

JEST5 $=$ JUMP $5+1$

I $3=1$

WRITE OUTPUT TAPE $10,4,13$

WRITE OUTPUT TAPE 10,5, , CARD

WR.ITE OUTPUT TAPE 10,11, CARDO

I $10=6$

VRITE OUTPUT TAPE $10,67, J U M P 1, J U M P 2, J U M P 3, J U M P 4$

I $10=110+4$

GO TO $(207,543), J E S T 5$

207 GO TO $(209,210)$, JEST? 
0

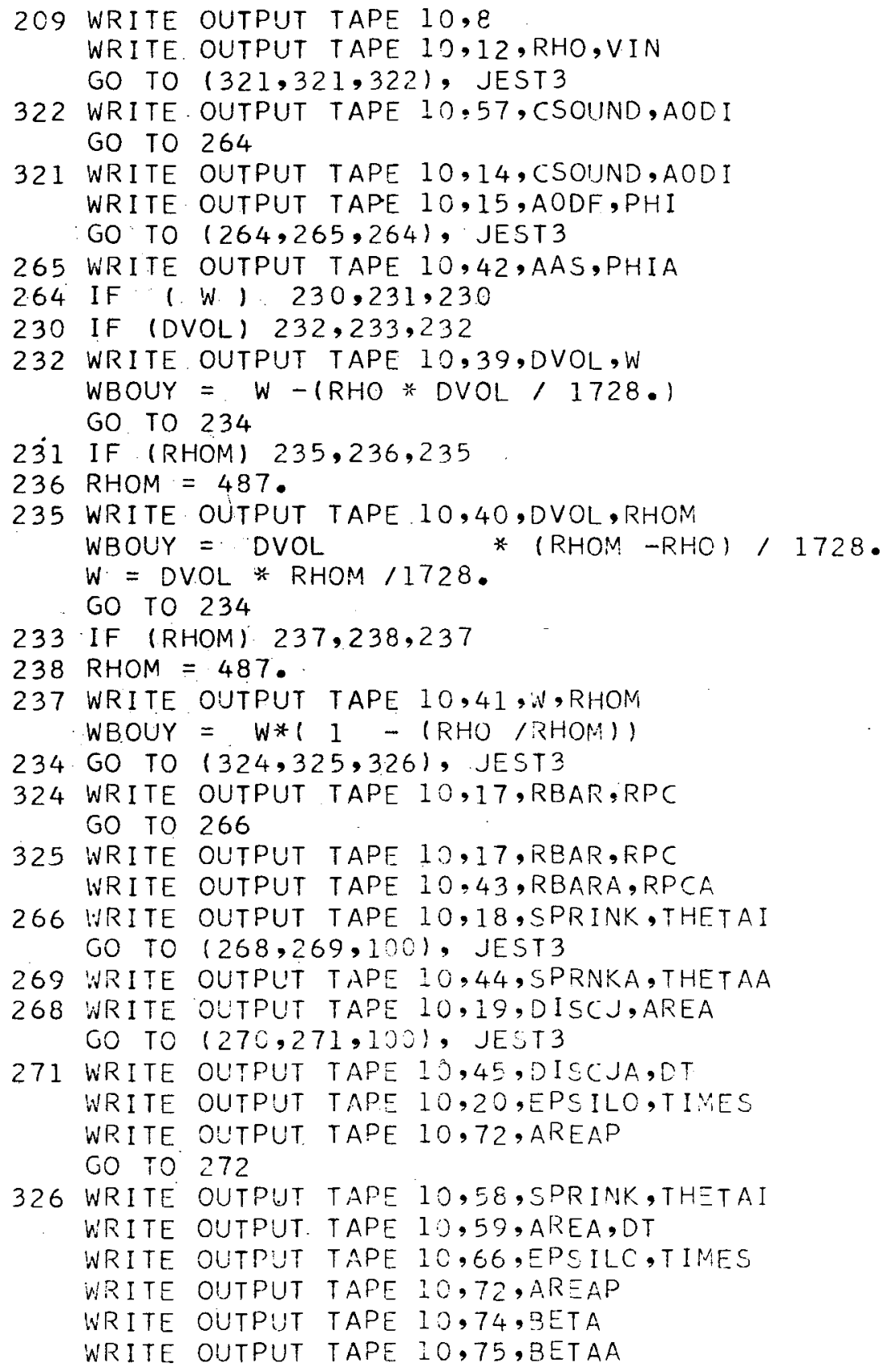


GO TO 272

270 WRITE. OUTPUT TAPE 10,20 ,EPSILO,TIMES

WRITE OUTPIT TAP $=10,16$, DT , AREAP

WRITE OUTPUT TAPE 10,74, BETA

272 GO TO $(309,310,3101$, JEST 4

310 WRITE OUTPUT TAPE $10,56, V M I N$

309 WRITE OUTPUT TAPE 10,21

WRITE OUTPUT TAPE 10,22

GO TO $(327,327,328)$, JEST3

327 WRITE OUTPUT TAPE 10,23

GO TO 329

328 WRITE OUTPUT TAPE 10,60

329 WRITE OUTPUT TAPE 10,24

WRITE OUTPUT TAPE 10,25 , (THET(II), DRAG(II), ANG(II), ADDJ(II),

ITV(II), VEL (I 1), I I =1, I2)

I $3=2$

WRITE OUTPUT TAPE $10,4,13$

WRITE OUTPUT TAPE 10,5, CARD

WRITE OUTPUT TAPE 10,11, CARD

210 IF (RHOM) $247,248,247$

248 RHOM $=487$.

247 WRITE OUTPUT TAPE 10,26

IF (W) $352,353,352$

$353 \mathrm{~W}=$ OVOL * RHOM / 1728 .

352 GO TO $(331,331,330)$, JEST3

330 WRITE OUTPUT TAPE 10,61

WRITE OUTPUT TAPE 10,62

WRITE OUTPUT TAPE 10,63

GO TO 332

231 WRITE OUTPUT TAPE 10,28

WRITE OUTPUT TAPE 10,29

WRITE OUTPUT TAPE 10,30

WRITE OUTPUT TAPE 10,31

332 I $10=13$

WRITE OUTPUT TAPE 10,24

180 CONT INUE

228 GO TO $(287,288,287)$, JEST 4

287 ATEM $=A O D I$

GO TO289

288 ATEM $=$ AODF

289 DO $104 \quad I 2=2,12$

I FI ATEM+PHITEM-THET(I 2$)$ ) 130,105,104

104 CONTINUE

131 WRITE OUTPUT TAPE 10,33 
GO TO 100

$105 D C O E=$ DRAG $(12)$

GO TO 354

130 EXPON = (ATEM+PHITEM-THET (I 2-1))/(THET(I 2)-THET(I 2-1)

$D C O E=((D R A G(I 2) / D R A G(I 2-1)) * * E X P N) * D R A G(I 2-1)$

354 GO TO $(107,290,107)$, JEST 4

294 JEST $4=2$

WRITE OUTPUT TAPE 10,52

$290 \mathrm{~V}=\mathrm{VMIN}$

GO TO $(286,286,335)$, JEST3

C THET = ANGLES CORRESPONDING TO INPUT DRAG COEFFICIENTS (DEG)

C DRAG = INPUT DRAG COEFFICIENT. (NONE)

C THE ABOVE IS A LINEAR INTFRPOLATION ON A SEMI-LOG PLOT

C THIS IS DCOE CORRESPONDING TO ATEM

107 GO TO $(370,370,371)$, JEST 3

$371 V=S Q R T F((9273.6 *(S K T E M *(A T E M-T H E T A T)+W B O U Y)) /(D C O E * R H O * A R E A))$ GO TO 372

$370 \mathrm{~V}=$ SQRTF(() (SKTEM*( (ATEM) -THETAT))+(WBOUY*RTEMI*SINF(ATEM

$1 / 57.3)) * 9273.6) /($ OCOE*RHO*AREA*RTEM $* \operatorname{COSF}((P H I T E M+A T E N 2) / 57 \cdot 3)))$

372 IF (VIN - V) $108,109,109$

$\begin{array}{ll}C & \text { THIS IS VELOCITY TO HOLD ATEM } \\ C & V \text { =VELOCITY OF FLUID IFT , SEC }\end{array}$

$C \cdot V$ VIN $=$ INITIAL VELOCITY OF FLUID (FT, SEC)

C THIS DETERMINES INITIAL DISC ANGLE IF NOT FULL OPEN.

AREA = AREA OF DISC. (IN SQ)

108 ATEM $=$ ATEM -.05

GO TO $(373,374,373)$, JUMP 14

374 IF (ATEM-AAS-PHIA+PHI) $37.5,375,293$

375 GO TO $(376,377,377)$, JEST 4

376 JEST $3=1$

WRITE OUTPUT TAPE 10,51

I $10=I 10+10$

377 RTEMI $=$ RBARA

RTEM2 = RPCA

$A T E M 2=B E T A A$

SKTEM $=$ SPRNKA

PHITEM $=$ PHIA

THETAT $=$ THETAA

DJTEM $=$ DISCJA

JUMP $14=1$

$A T E M=A T E M-P H I A+P H I$

$D T=D T / 10$.

$123=1$

WRITE OUTPUT TAPE 10,71 
GO TO 293

373 IF (A.TEM-ADDF) $294,294,293$

293 IF (ATEM+PHITEM-THET(I2-1)) 132,133,130

$13212=12-1$

GO TO 130

233 DCOE = DRAG $(12-1)$

GO TO 107

$335 \mathrm{AODT}=$ ATEM

GO TO 336

109 GO TO $(286,379,335)$, JEST3

379 GO TO $(286,286,380)$, JEST4

380 GO TO $(286,381)$, JUMP 14

381 JEST $3=1$

$286 \mathrm{AODT}=$ A.TEM $/ 57.3$

$336 \mathrm{~A} 1 \mathrm{DT}=\mathrm{A} 1 \mathrm{DI}$

$A 2 D T=A 2 D I$

$A 2 D T D T=A 2 D I$

C AODT = ANGLE OF DISC CCW FROM VERTICALLY DOWN.A STANDS FOR ANGLE,

$C \quad$ CD STANDS FOR ZEROTH DERIVATIVE AND T STANDS FOR TIME T

C AODI = INITIAL ANGLE OF DISC

AIDT =FIRST DERIVATIVE OF ANGLE AT TIME T• (RAD/SEC)

AIDI = INITIAL VALUE OF FIRST DERIVATIVE. (RAD/SEC)

- AZDT = SECOND DERIVATIVE AT TIME T. (RAD/SEC SQ)

A2DI = INITIAL VALUE OF SECOND DERIVATIVE. (RAD/SEC SQ)

AODTDT $=A O D$ AT $T+D T$

$A 1 D T D T=A 1 D$ AT $T+D T$

$A 2 D T D T=A 2 D$ AT $T+D T$

DT = TIME INCRENIET FOR FINITE DIFFERENCE METHOD OF INTEGRATION. (SEC)

GO TO $(295,297,297)$, JEST 4

295 DO $241,12=2,12$

IF (VIN - VELI I 21$) 241,240,239$

241. CONT INUE

WRITE OUTPUT TAPE 10,46

GO TO 100

240 TIMEI = TV (I 2)

C TV IS TIME OF INPUT VELOCITY VEL (FT/SEC) (SEC)

GO TO 242

297 DO 298 I $2=2,12$

IF (VIN - VEL(I2)) 239,240,298

298 CONTINUE

WRITE OUTPUT TAPE 10,46

GO TO 100

239 TIMEI $=(($ (TVII2) - TV $(12-1)) *(V I N-V E L(I 2))),($ VEL(I2)-VEL(I2-1) 


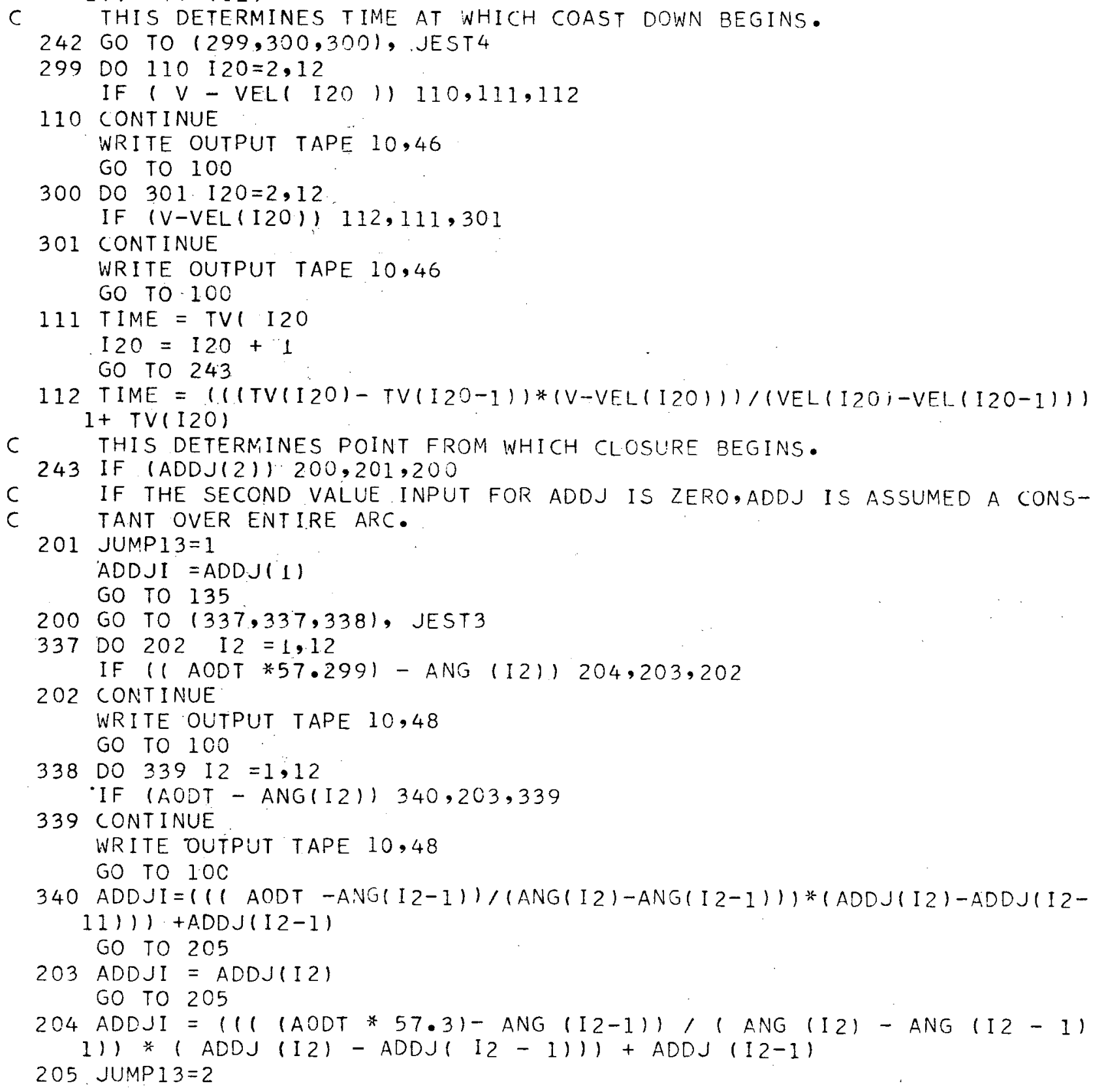


135 IF (TIME - TV(I 20)) $244,246,246$

246 I $20=120+1$

244 VTEM $=((T I M E+D T-T V(120)) *(V E L(I 20)-V E L(I 20-1))) /(T V(I 20)-T V 1$ $1(20-1))+V E L(I 20)$

118 AIDTDT $=((($ A2DTDT +A2DT $) * D T) / 2 \cdot)+A 1 D T$ AODTDT $=(((D T * 2) / 6 \cdot) *(A 2 D T D T+(2 \bullet * A 2 D T)))+(D T * A 1 D T)+A O D T$ GO TO $(341,341,342)$, JEST3

$342.5 T O R Q=$ SKTEM * (AODTDT - THETAT) DTORQ $=$ ABSF $(V-(A 1 D T D T / 12)) *.(V-(A 1 D T D T / 12)) * A R E A * D C O E * R H$. 19273.6

$A T O R Q=D T C R Q-S T O R Q$

$A 2 D C=A T O R Q /((W / 32.2)+A D D J I)$

GO TO 343

341 WTORQ = WBOUY * RTEMI * SINF (AODTDT)

C WTORQ =WEIGHT TORQUE (IN-LBS)

RTEMI = DISTANCE CG TO PIVOT (IN)

STORQ $=$ SKTEM * ( $($ AODTDT * $* 37.3)-$ THETAT)

STORQ $=$ SPRING TORQUE (IN-LBS)

DTORQ $=$ DCOE*RHO*AREA*RTEM2*COSF $((P H I T E M+A T E M 2) / 57.3) * V / A B S F(V)$ $1 / 9273.6 * 1 \quad(V-R T E M 2 / 12 *$ AIDTDT*COSF (ACDTDT-ATEM2:57.3) $* * 2+$

$551 \mathrm{DT}=\mathrm{DT} / 10$.

WRITE OUTPUT TAPE $10,69,0^{\circ}$

AODTDT $=$ AODT

AIDTDT =AIDT

A2DTDT $=$ A2DT

$110=110+10$

GO TO 244

$552 \mathrm{DT}=10 . * \mathrm{DT}$

WRITE OUTPUT TAPE 10,70

GO. TO 100

IF (AODTDT-1.OE 10) $118,118,550$ 


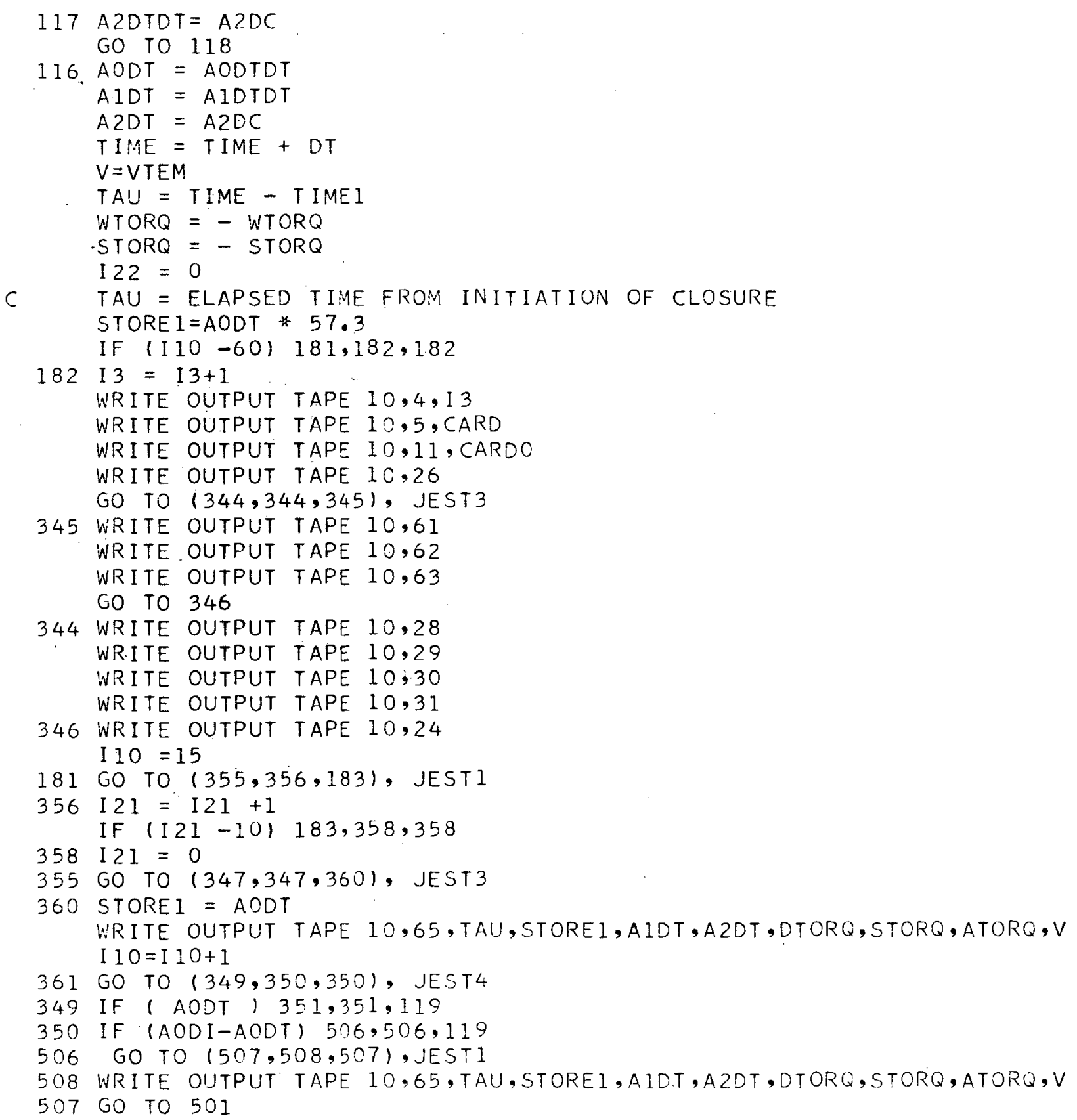

508 WRITE OUTPUT TAPE 10,65 , TAU, STOREI, AIDT, A 2DT, DTORQ, STORQ, ATORQ, V

507 GO TO 501 
351 CPVEL $=($ RHO * V* CSOUND) $/ 4636.8$

SOVOL = AREA $* A T E M$

GO TO $(505,502,505)$, JEST 1

502 WRITE OUTPUT TAPE. 10,65 , TAU,STORE1, A1DT, A2OT, DTORQ, STORQ, ATORQ,V

505 GO TO 281

347 WRITE OUTPUT TAPE 10,32, TAU,STORE1, AIDT, A2DT, WTORQ, LTORQ, STORQ, $1 A T O R Q, V$

$I 10=I 10+1$

183 50 TO $(282,283,361)$, JEST3

282 GO TO $(302,303,303)$, JEST 4

302 IF ( ( AODF /57.3)-AODT) 119,122,122

303 IF ( $A$ AODI $/ 57.3)$ - AODT) $304,304,119$

30460 TO $(501,500,501)$, JEST1

500 V!RITE OUTPUT TAPE 10,32, TAU,STORE1, A1DT, A2DT, NTORQ, DTORQ, STORQ, IATORQ, $V$

501 WRITE OUTPUT TAPE 12,55

$123=123+1$

GO TO $(100,556), 123$

$556 \mathrm{DT}=\mathrm{DT} * 10$.

GO. TO 100

283 GO TO $(305,306,306)$, JEST 4

305 IF (AODT*57.3-AAS-PHIA+PHI) $284,284,119$

306 IF (( AAS / 57.3) - AODT) 307.307,119

307 JEST $3=$ JEST $3-1$

WRITE OUTPUT TAPE 10,51

$110=110+10$

RTEMI = RBAR

RTEM2 = RPC

$A T E M 2=B E T A$

PHITEM=PHI

SKTEM = SPRINK

THETAT = THETAI

DJTEM $=$ DISCJ

AIDT = (AIDT* RBARA) /RBAR

$A O D T=A . O D T+((P H I A-P H I) / 57.3)$

$D T=D T * 10$

I $23=123-1$

GO TO 119

284 WRITE OUTPUT TAPE 10,51

DT $=0 T / 10$.

$123=123+1$

If $($ I $10-50) 999,999,998$

$999 \quad 13=13+1$

WRITE OUTPUT TAPE $10,4,13$ 
WRITE OUTPUT TAPE 10,5, CARD

WRITE OUTPUT TAPE 10,11 , CARDO

WRITE OUTPUT TAPE 10,26

996 WRITE OUTPUT TAPE 10,28

WRITE OUTPUT TAPE 10,29

WRITE OUTPUT TAPE 10,30

WRITE OUTPUT TAPE 10,31

995 WRITE OUTPUT TAPE 10,24 I $1 O=1.5$

998 WRITE OUTPUT TAPE 10,71

I $10=110+10$

$A O D T=A O D T-((P H I A-P H I) / 57.3)$

$I 10=110+10$

JEST3 $=$ JEST $3-1$.

RTEM1 = RBARA

RTEM2 = RPCA

ATEM2 = BETAA

SKTEM = SPRNKA

PHITEM $=$ PHI A

THETAT $=$ THETAA

$D J T E M=D I S C J A$

AIDT = (AIDT*RBAR) / R3ARA

119 IF (TAU - TIMES) $138,138,229$

122 DPVEL $=($ RHO *V*CSOUND $) /(4636.8)$

DPVEL = EXTINGUISHED VELOCITY DELTA P

GO TO $(503,504,503)$, JEST I

504 WRITE OUTPUT TAPE 10,32 , TAU,STOREI, AIDT, A2DT, WTORQ, DTORQ, STORQ, I ATORQ, $V$

503 JEST3 $=$ JUMP $3+1$

GO TO $(276,277)$, JEST 3

276 SOVOL $=$ AREA * COSF $(P H I / 57.3) * R P C *((A T E M-A O D F) / 57.31$ GO TO 281

280 SOVOL $=A R E A / 57.3 *((C O S F(P H I / 57 \cdot 3) * R P C *(A T E M-A A S-P H I A+P H I))+(C O S F$ $1(\mathrm{PH} I A / 57.3) * \mathrm{RPCA} *(A A S-A O D F))$ GO TO 281

277 IF (ATEM-AAS-PHIA+PHI) $279,279,280$

279 SOVOL = AREA * COSF $(P H I A / 57.3) *$ RPCA * (ATEM - AODF) 157.3 CSOUND $=$ SONIC VELOCITY

SOVOL = SWEPT OUT VOUME DF OISC. (IN CUBE)

TIMES = TIME AT WHICH PROBLEM IS TO STOP

TZERO = TIME AT WHICH VELOCITY PASSES THROUGH ZERO

281 DO 125 I $2=1,12$

IF (VEL(I2)) $123,124,125$

125 CONTINUE 
WRITE OUTPUT TAPE 10,46

GO TO 100

124 TZERO = TV(I 2$)$

I $2=I 2+1$

GO TO 129

123 TZERO = ( TV (I 2)-TV(I2-I))*VEL(I 2-1)/(VEL(I2-1)-VEL(I2))+TV(I2-1)

1)

129. RFVOL $1=0$.

RFVOL = INTEGRATED REVERSE FLOW VOLUME.

RFVOL $=0.5 *(T Z E R O-T V(12)) * V E L(12) * A R E A P * 12$.

IF (SOVOL -RFVOL) $128,126,127$

126 VTEM = VEL(I2)

GO TO 136

127. RFVOLI = RFVOL

$I 2=I 2+I$

RFVOL =RFVOL $1+(T V(I 2-1)-T V(I 2)) * 0.5 *(V E L(I 2)+V E L(I 2-1)) * A R E A P * 12$.

IF ( SOVOL - RFVOL ' 400,126,127

400 TTEMI = TV $(I 2-1)$.

$T T E M 2=T V(12-1)$

VTEMI = VEL $(12-1)$

GO TO 362

128 TTEMI $=$ TZERO

TTEMZ = TZERO

RFVOL $1=0$.

VTEMI $=0$.

362 TTEM2 = TTEM2 + DT

VTEM = (VEL(I 2)-VEL(I2-1))*(TTEM2-TV(I2))/(TV(I2)-TV(I2-1))+VEL

I ( 12 )

RFVOL=RFVOL $1+((T T E M 1-T T E M 2) * 0.5 *(V T E M+V T E M 1)) * A R E A P * 12$

IF (SOVOL -RFVOL) $136,136,362$

136 DPVOL $=($ RHO * CSOUND * VTEM $) /(4636.8)$

$123=123+1$

GO TO $(554,555,994)$, I23

$994 D^{\circ} T=D T * 100$.

GO TO 554

$555 \mathrm{DT}=\mathrm{DT} * 10$.

554 IF (I 10-50) $185,184,184$

$18413=13+1$

WRITE OUTPUT TAPE $10,4,13$

WRITE OUTPUT TAPE 10,5, CARD

WRITE OUTPUT TAPE 10,11 , CAPDO

WIRITE OUTPUT TAPE 10,26

185 GO TO $(529,510,509)$, JEST 3

510 WRITE OUTPUT TAPE.10,68, ATEM 
GO TO 511

509 WRITE OUTPUT TAPE 10,34 , ATEM

511 WRITE OUTPUT TAPE $10,35, \mathrm{~V}$

WRITE. OUTPUT TAPE 10,36 , DPVEL

WRITE OUTPUT TAPE $10,37, V T E M$

WRITE OUTPUT TAPE 10,36 ,DPVOL

GO TO 100

138 DO 139 I $2=2,12$

$Z=A O D T * 57 \cdot 3+P H I T E M-A T A N F(-R T E M 2 * A I D T D T * S I N F(A O D T-A T E M 2 / 57 \cdot 3)$

$1 /(12 * V-R T E M 2 * A 1 D T D T * \operatorname{COSF}($ AODT $-A T E M 2 / 57.3) 1)$

IF $(Z-T H E T(I 2)) 141,140,139$

139 CONTINUE

WRITE OUTPUT TAPE 10,33

GO TO 100

140 DCOE = DRAG(I2)

GO TO $(135,200)$, JUMP 13

141 EXPON $=(Z-T H E T($ I $2-1)) /($ THET (I 2)-THET (I 2-1)

DCOE $=(1$ DRAG (I2) / DRAG (I2-1)) * EXPON) * DRAG(I2-1)

GO TO $(135,200)$, JUMPI 3

229 WRITE OUTPUT TAPE 10,38 , TIMES

GO TO 100

END $(0,1,0,1,0)$

COMPLETE 
2THIS IS A SAMPLE PROBLEM OF A SIMPLE SWING TYPE CHECK VALVE 3FOR THE SLAM (MO188) CODE.

$562.4 \quad 30$. 5000 .

675 .

$675 \cdot-20$

8. -30.85

$10 \quad 1500 . \quad .0096$

12

17

$.05 \quad 3$.

$30 . \quad-25$.

.01

10 .

60.

75 .

10 .

1

2THIS IS A SAMPLE PROBLEM OF AN ARTICULATED SWING TYPE CHECK 3VALVE FOR THE SLAM (MO188) CODE.

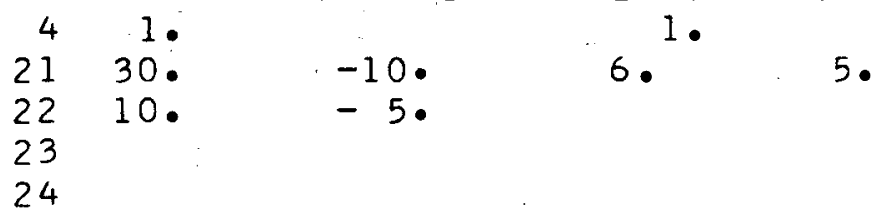


SLAM CODE MO188 CHECK VALVE SLAM PRESSURE SIJRGE.

THIS IS A SAMPLE PROBLEM OF A SIMPLE SWING TYPE CHECK VALVE

FOR THE SLAM (MO188) CODE.

THE OPTIONS CHOSEN ARE

OPTION 1.0 OPTION $3=0$ OPTION $4=0$

INPUT EDIT.

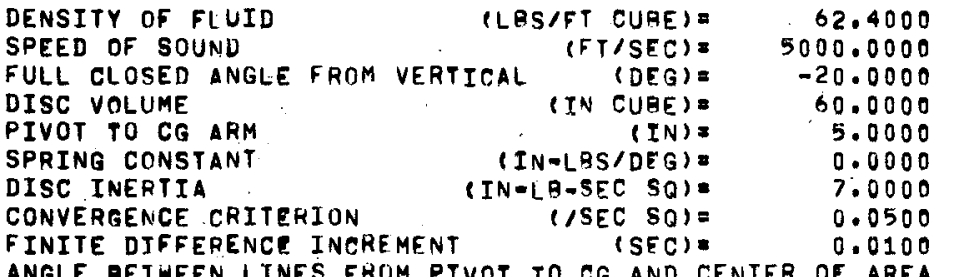

INITIAL FLUTB VELACITY

FULL OPEN ANGLE FOOM VERTICAL

$(D E G)=$

DISC FACE ANOL

DENSITY OF DISE MFTAL

PIVOT TO CENFE OF AREA

INITIAL SDRTNG DISPLACEMENT

MAXIMUM INTEGRAT

TION TIME

FINITE DIFFERENCR INCREMENT (SEC) C

(DEG) =

(LBS)

30.0000

DOWLE DER DRAG
COEFFICIENT

VALUE

ADDED INERTIA

ANGLE

ANGLE

VALUE

(IN) $=$

(10.0000

$-30.0000$

85.0000

0.0000

0.0000

0.0000

0.0000

0.0000

0.0000

0.0000

0.0000

0.0000

1500.0000

0.0095

0.0000

0.0000

0.0000

0.0000

0.0000

0.0000

0.0000

0.0000

0.0000

0.0000

0.0 no

0.0000

0.0000

0.0000

0.0000

0.0000

0.0000

0.0000

0.0000

0.0000

0.0000
0.0000

0.0000

0.0000

0.0000

0.0000

0.0000

0.0000

0.0000

0.0000

0.0000
0.0000

IN SQ

487.0000

6.0000

0.0000

(IN SO)= $\quad 3.0000$

10.0000

75.000

WATER
VELOCITY

TIME,

VELOCITY

0.0000

30.0000

3.0000

3.0000

0.0000

0.0000

0.0000

0.0000

0.0000

0.0000

0.0000

0.0000

0.0000

$-25.0000$

0.0000

0.0000

0.0000

0.0000

0.0000

0.0000

0.0000

0.0000

0.0000 
THIS IS A SAMPLE PROBLEM OF A SIMPLE SWING TYPE CHECK VALVE FOR THE SLAM (MO188) CODE.

OUTPUT

\begin{tabular}{|c|c|c|c|c|c|c|c|c|}
\hline $\begin{array}{l}\text { I IME } \\
\text { (SEC) }\end{array}$ & $\begin{array}{l}\text { ANGLE OF } \\
\text { DISC } \\
\text { FROM VEAT } \\
\text { (DEGREES) }\end{array}$ & $\begin{array}{l}\text { DISC } \\
\text { ANGULAR } \\
\text { VELOCITY } \\
\text { (RAD/SEC) }\end{array}$ & $\begin{array}{c}\text { DISC } \\
\text { ANGULAR } \\
\text { ACCELER. } \\
\text { (RAD/SEC SO) }\end{array}$ & $\begin{array}{l}\text { WEIGHT } \\
\text { MOMENT } \\
\text { (IN-LBS) }\end{array}$ & $\begin{array}{l}\text { FLOW } \\
\text { MOMENT } \\
\text { (IN-LES) }\end{array}$ & $\begin{array}{l}\text { SPRING } \\
\text { MOMENT } \\
\text { (IN-LBS) }\end{array}$ & $\begin{array}{l}\text { INERTIA } \\
\text { MOMENT } \\
\text { (IN-LBS) }\end{array}$ & $\begin{array}{l}\text { WATEK } \\
\text { VELOCLTY } \\
\text { (FT/SEC) }\end{array}$ \\
\hline $\begin{array}{l}0.012 \\
0.022 \\
0.032 \\
0.042 \\
0.052 \\
0.062 \\
0.072 \\
0.082 \\
0.092 \\
0.102 \\
0.112 \\
0.122 \\
0.132 \\
0.142 \\
0.152 \\
0.162 \\
0.172 \\
0.182 \\
0.192 \\
0.202 \\
0.212 \\
0.222 \\
0.232 \\
0.242 \\
0.252 \\
0.262 \\
0.272 \\
0.282 \\
0.292 \\
0.302 \\
0.312 \\
0.322 \\
0.332 \\
0.342 \\
0.352 \\
0.362 \\
0.372 \\
0.382 \\
0.392 \\
0.402 \\
0.412 \\
0.422 \\
0.432 \\
0.442 \\
0.452 \\
0.462 \\
0.472\end{array}$ & $\begin{array}{l}64.7000 \\
64.6997 \\
64.6979 \\
64.6979 \\
64.6832 \\
64.6674 \\
64.6440 \\
64.6116 \\
64.5689 \\
64.5147 \\
64.4478 \\
64.3671 \\
64.2714 \\
64.1599 \\
64.0316 \\
63.8897 \\
63.7214 \\
63.5380 \\
63.3349 \\
63.1115 \\
62.8673 \\
62.6020 \\
62.3191 \\
62.0063 \\
61.6736 \\
61.3226 \\
60.9472 \\
60.5495 \\
60.1295 \\
59.6870 \\
59.2223 \\
58.7353 \\
58.2263 \\
57.6955 \\
57.1433 \\
56.5699 \\
55.9798 \\
55.3614 \\
54.7271 \\
54.0733 \\
53.4005 \\
52.7093 \\
52.0001 \\
51.2734 \\
50.5298 \\
49.7698 \\
48.9938\end{array}$ & $\begin{array}{l}0.0000 \\
-0.0014 \\
-0.0055 \\
-0.0124 \\
-0.0218 \\
-0.0338 \\
-0.0483 \\
-0.0551 \\
-0.0842 \\
-0.1053 \\
-0.1285 \\
-0.1536 \\
-0.1805 \\
-0.2090 \\
-0.2391 \\
-0.2705 \\
-0.3032 \\
-0.3371 \\
-0.3720 \\
-0.4078 \\
-0.4445 \\
-0.4818 \\
-0.5197 \\
-0.5579 \\
-0.5966 \\
-0.6355 \\
-0.6745 \\
-0.7136 \\
-0.7526 \\
-0.7916 \\
-0.8306 \\
-0.8691 \\
-0.9075 \\
-0.9451 \\
-0.9823 \\
-1.0188 \\
-1.0547 \\
-1.0898 \\
-1.1242 \\
-1.1577 \\
-1.1904 \\
-1.2222 \\
-1.2531 \\
-1.2831 \\
-1.3122 \\
-1.3405 \\
-1.3670\end{array}$ & $\begin{array}{l}-0.0000 \\
-0.2776 \\
-0.5503 \\
-0.8167 \\
-1.0755 \\
-1.3255 \\
-1.5659 \\
-1.7959 \\
-2.0148 \\
-2.2222 \\
-2.4177 \\
-2.6010 \\
-2.7720 \\
-2.9307 \\
-3.0770 \\
-3.2110 \\
-3.3328 \\
-3.4425 \\
-3.5403 \\
-3.6264 \\
-3.7011 \\
-3.7644 \\
-3.8168 \\
-3.8583 \\
-3.8893 \\
-3.9102 \\
-3.9210 \\
-3.9221 \\
-3.9139 \\
-3.8965 \\
-3.8704 \\
-3.8359 \\
-3.7932 \\
-3.7429 \\
-3.6855 \\
-3.6214 \\
-3.5513 \\
-3.4758 \\
-3.3956 \\
-3.3115 \\
-3.2245 \\
-3.1355 \\
-3.0455 \\
-2.9559 \\
-2.8678 \\
-2.7827 \\
-2.7021\end{array}$ & 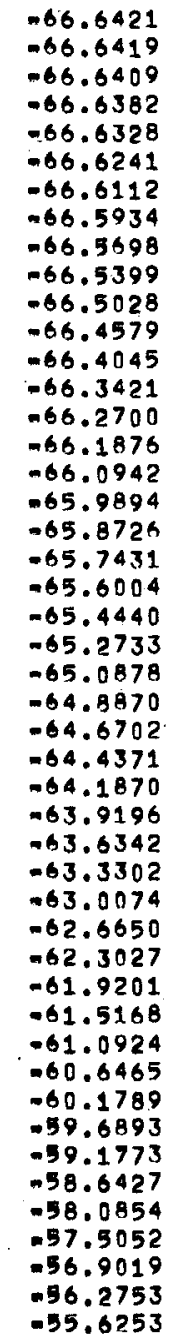 & $\begin{array}{l}65.6421 \\
64.6986 \\
62.7890 \\
60.92116 \\
59.9047 \\
57.3454 \\
55.6496 \\
54.0219 \\
52.4660 \\
50.9845 \\
49.5791 \\
48.2910 \\
47.0105 \\
45.8274 \\
44.7312 \\
43.7108 \\
42.7649 \\
41.8920 \\
41.0903 \\
40.3580 \\
39.6979 \\
39.0930 \\
38.5560 \\
38.0795 \\
37.6615 \\
37.2991 \\
36.9903 \\
36.7333 \\
36.5225 \\
3643584 \\
36.2374 \\
36.1564 \\
36.1126 \\
36.092 \\
36.1218 \\
36.1670 \\
36.2334 \\
36.3161 \\
36.4098 \\
36.5085 \\
36.4058 \\
36.6945 \\
36.7668 \\
36.8142 \\
36.8274 \\
36.7965 \\
36.7106\end{array}$ & $\begin{array}{l}0.0000 \\
0.0000 \\
0.0000 \\
0.0000 \\
0.0000 \\
0.0000 \\
0.0000 \\
0.0000 \\
0.0000 \\
0.0000 \\
0.0000 \\
0.0000 \\
0.0000 \\
0.0000 \\
0.0000 \\
0.0000 \\
0.0000 \\
0.0000 \\
0.0000 \\
0.0000 \\
0.0000 \\
0.0000 \\
0.0000 \\
0.0000 \\
0.0000 \\
0.0000 \\
0.0000 \\
0.0000 \\
0.0000 \\
0.0000 \\
0.0000 \\
0.0000 \\
0.0000 \\
0.0000 \\
0.0000 \\
0.0000 \\
0.0000 \\
0.0000 \\
0.0000 \\
0.0000 \\
0.0000 \\
8.0000 \\
0.0000 \\
0.0000 \\
0.0000 \\
8.0000 \\
0.0000\end{array}$ & $\begin{array}{l}-0.0000 \\
-1.9434 \\
-3.8519 \\
-5.7166 \\
-7.5282 \\
-9 . .2787 \\
-10.9616 \\
-12.5715 \\
-14.1038 \\
-15.5554 \\
-16.9236 \\
-18.2069 \\
-19.4041 \\
-20.5147 \\
-21.5388 \\
-22.4768 \\
-23.3293 \\
-24.0974 \\
-24.7822 \\
-25.3851 \\
-25.9075 \\
-26.3510 \\
-26.7173 \\
-27.0083 \\
-27.2254 \\
-27.3711 \\
-27.4468 \\
-27.4548 \\
-27.3971 \\
-27.2757 \\
-27.0928 \\
-26.8510 \\
-26.5524 \\
-26.2005 \\
-25.7983 \\
-25.3498 \\
-24.8590 \\
-24.3304 \\
-23.7692 \\
-23.1808 \\
-22.5715 \\
-21.9483 \\
-21.3187 \\
-20.6910 \\
-20.0745 \\
-19.4788 \\
-18.0148\end{array}$ & $\begin{array}{l}29.4067 \\
29.0467 \\
28.6067 \\
28.1667 \\
27.7467 \\
27.2067 \\
26.8467 \\
26.4067 \\
25.9067 \\
25.5067 \\
25.0067 \\
24.6467 \\
24.2067 \\
23.7067 \\
23.3267 \\
22.8067 \\
22.4467 \\
22.0067 \\
21.5067 \\
21.1267 \\
20.6067 \\
20.2467 \\
19.8067 \\
19.3067 \\
18.9267 \\
18.4067 \\
18.0467 \\
17.6067 \\
17.1067 \\
16.7267 \\
16.2067 \\
15.8467 \\
15.4067 \\
14.9067 \\
14.5267 \\
14.0067 \\
13.6467 \\
13.2067 \\
12.7067 \\
12.3267 \\
11.8067 \\
11.4467 \\
11.0067 \\
10.5067 \\
10.1267 \\
9.6067 \\
9.2967\end{array}$ \\
\hline
\end{tabular}


THIS IS a sample problem uf a simple sining type check valve FOR THE SLAM (MO188) CODE.

OUTPUT

\begin{tabular}{|c|c|c|c|c|c|c|c|c|}
\hline $\begin{array}{l}\text { TIME } \\
\text { (SEC) }\end{array}$ & $\begin{array}{l}\text { ANGLE OF } \\
\text { DISC } \\
\text { FROM VERT } \\
\text { (DEGREES) }\end{array}$ & $\begin{array}{l}\text { DISE } \\
\text { ANGULAR } \\
\text { VELOCITY } \\
\text { (RAD/SEC) }\end{array}$ & $\begin{array}{c}\text { DISC } \\
\text { ANGULAR } \\
\text { ACCELER. } \\
\text { (RAD/SEC SO) }\end{array}$ & $\begin{array}{l}\text { WEIGHT } \\
\text { MOMENT } \\
\text { (IN-LBS) }\end{array}$ & $\begin{array}{l}\text { FLOW } \\
\text { MOMENT } \\
\text { (IN-LAS) }\end{array}$ & $\begin{array}{l}\text { SPRING } \\
\text { MOMENT } \\
\text { (IN-LES) }\end{array}$ & $\begin{array}{l}\text { INERTIA } \\
\text { MOMENT } \\
(I N-L B S)\end{array}$ & $\begin{array}{l}\text { WATEK } \\
\text { VELOCLTY } \\
\text { (FT/SEC) }\end{array}$ \\
\hline $\begin{array}{l}0.482 \\
0.492 \\
0.502 \\
0.512 \\
0.522 \\
0.532 \\
0.542 \\
0.552 \\
0.562 \\
0.572 \\
0.582 \\
0.592 \\
0.602 \\
0.612 \\
0.622 \\
0.632 \\
0.642 \\
0.652 \\
0.662 \\
0.672 \\
0.682 \\
0.692 \\
0.702 \\
0.712 \\
0.722 \\
0.732 \\
0.742 \\
0.752 \\
0.762 \\
0.772 \\
0.782 \\
0.792 \\
0.802 \\
0.812 \\
0.822 \\
0.832 \\
0.842 \\
0.852 \\
0.862 \\
0.872 \\
0.882 \\
0.892 \\
0.902\end{array}$ & $\begin{array}{l}48.2023 \\
47.3958 \\
46.5746 \\
45.7390 \\
44.8892 \\
44.0254 \\
43.1478 \\
42.2564 \\
41.3510 \\
40.4316 \\
39.0976 \\
38.5486 \\
37.5839 \\
36.6028 \\
35.6084 \\
34.5876 \\
33.5512 \\
32.4941 \\
31.4149 \\
30.3123 \\
29.1849 \\
28.0318 \\
26.8519 \\
25.6452 \\
24.01132 \\
23.1567 \\
21.8754 \\
20.5669 \\
19.2261 \\
17.8443 \\
16.4080 \\
14.8977 \\
13.2864 \\
11.5374 \\
9.6023 \\
7.4177 \\
4.9014 \\
1.9469 \\
-1.5832 \\
-5.8806 \\
-11.1961 \\
-17.9175 \\
-26.7435\end{array}$ & $\begin{array}{l}-1.3945 \\
-1.4205 \\
-1.4458 \\
-1.4708 \\
-1.4953 \\
-1.5195 \\
-1.5437 \\
-1.5679 \\
-1.5922 \\
-1.6172 \\
-1.6429 \\
-1.6697 \\
-1.6976 \\
-1.7271 \\
-1.7582 \\
-1.7912 \\
-1.8264 \\
-1.8638 \\
-1.9035 \\
-1.9455 \\
-1.9896 \\
-2.0356 \\
-2.0827 \\
-2.1285 \\
-2.1717 \\
-2.2140 \\
-2.2588 \\
-2.3098 \\
-2.3726 \\
-2.4544 \\
-2.5645 \\
-2.7147 \\
-2.9200 \\
-3.1987 \\
-3.5739 \\
-4.0749 \\
-4.7385 \\
-5.6139 \\
-6.7676 \\
-8.2974 \\
-10.3616 \\
-13.2762 \\
-17.9333\end{array}$ & $\begin{array}{r}-2.6277 \\
-2.5611 \\
-2.5041 \\
-2.4586 \\
-2.4265 \\
-2.4097 \\
-2.4101 \\
-2.4296 \\
-2.4699 \\
-2.5323 \\
-2.6181 \\
-2.7282 \\
-2.8628 \\
-3.0216 \\
-3.2033 \\
-3.4056 \\
-3.6247 \\
-3.8550 \\
-4.0882 \\
-4.3130 \\
-4.5135 \\
-4.6682 \\
-4.7641 \\
-4.3948 \\
-4.2374 \\
-4.2788 \\
-4.6668 \\
-5.5266 \\
-7.0156 \\
-9.3248 \\
-12.6838 \\
-17.3644 \\
-23.6930 \\
-32.0702 \\
-43.0065 \\
-57.1794 \\
-75.5418 \\
-99.4946 \\
-131.2548 \\
-174.7041 \\
-238.1548 \\
-344.7949 \\
-586.6359\end{array}$ & $\begin{array}{l}-54.9519 \\
-54.2549 \\
-53.5342 \\
-52.7895 \\
-52.0206 \\
-51.2275 \\
-50.4096 \\
-49.5668 \\
-48.5985 \\
-47.8043 \\
-46.8834 \\
-45.9349 \\
-44.9578 \\
-13.9510 \\
-12.9132 \\
-11.8429 \\
-40.7385 \\
-39.5982 \\
-38.4202 \\
-37.2025 \\
-35.9434 \\
-34.6410 \\
-33.2939 \\
-31.9016 \\
-30.4654 \\
-28.9863 \\
-27.4636 \\
-25.8944 \\
-24.2725 \\
-22.5871 \\
-20.8212 \\
-18.9504 \\
-16.9400 \\
-14.7426 \\
-12.2954 \\
-9.5161 \\
-6.2979 \\
-2.5042 \\
2.0391 \\
7.5520 \\
14.3121 \\
22.6767 \\
33.1694\end{array}$ & $\begin{array}{r}36.5582 \\
36.3274 \\
36.0052 \\
35.5793 \\
35.0349 \\
34.3504 \\
33.5388 \\
32.5598 \\
31.4096 \\
30.0785 \\
28.5566 \\
26.8375 \\
24.9182 \\
22.0001 \\
20.4902 \\
18.0037 \\
15.3653 \\
17.6132 \\
9.8076 \\
7.0117 \\
4.3491 \\
1.9638 \\
-0.0550 \\
1.1379 \\
0.8036 \\
-0.9650 \\
-5.2037 \\
-12.7918 \\
-24.8366 \\
-42.6866 \\
-67.9652 \\
-102.6003 \\
-148.9109 \\
-209.7485 \\
-288.7504 \\
-390.7400 \\
-522.4947 \\
-693.0579 \\
-920.8225 \\
-1230.4806 \\
-1681.3961 \\
-2436.0411 \\
-4139.6209\end{array}$ & $\begin{array}{l}0.0000 \\
0.0000 \\
0.0000 \\
0.0000 \\
0.0000 \\
0.0000 \\
0.0000 \\
0.0000 \\
0.0000 \\
8.0000 \\
0.0000 \\
0.0000 \\
0.0000 \\
0.0000 \\
0.0000 \\
0.0000 \\
0.0000 \\
0.0000 \\
0.0000 \\
0.0000 \\
0.0000 \\
0.0000 \\
0.0000 \\
0.0000 \\
0.0000 \\
0.0000 \\
0.0000 \\
0.0000 \\
0.0000 \\
0.0000 \\
0.0000 \\
0.0000 \\
0.0000 \\
0.0000 \\
0.0000 \\
0.0000 \\
0.0000 \\
0.0000 \\
0.0000 \\
0.0000 \\
0.0000 \\
0.0000 \\
0.0000\end{array}$ & $\begin{array}{r}-18.3937 \\
-17.9275 \\
-17.5289 \\
-17.2102 \\
-16.9857 \\
-16.8681 \\
-16.8708 \\
-17.0070 \\
-17.2890 \\
-17.7259 \\
-18.3268 \\
-19.0973 \\
-20.0395 \\
-21.1509 \\
-22.4229 \\
-23.8392 \\
-25.3731 \\
-26.9850 \\
-28.6176 \\
-30.1909 \\
-31.5943 \\
-32.6772 \\
-33.3489 \\
-30.7637 \\
-29.6619 \\
-29.9513 \\
-32.6673 \\
-38.6862 \\
-49.1091 \\
-65.2737 \\
-88.7864 \\
-121.5507 \\
-165.8509 \\
-224.4911 \\
-301.0458 \\
-400.2560 \\
-528.7926 \\
-696.4620 \\
-918.7834 \\
-1222.9286 \\
-1667.0839 \\
-2413.5645 \\
-4106.4514\end{array}$ & 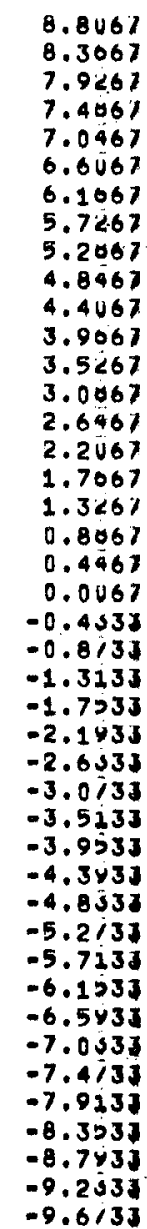 \\
\hline
\end{tabular}


SLAM CODF MO188 CHECK VALVE SLAM PRESSURE SURGE,

THIS IS a SAMPLE PRORLEM OF a SIMPLE SWING TYPE CHECK VALVE FOR THE SLAM (MOQB8) CODE.

OUTPUT

THE INITIAL VALVE ANGLE

THE EXTINGUISHED VELOCITY RASED ON THE EOUATIONS UF MOTION

THE DELTA P CORRESFONDING TO THIS EXTIOUISHED VELOCITY

TH ON THE SWEPT OUT VOLUME THETRY

THE DELIA P CORRESPONDING TO THIS EXTIGUISHED VELOCITY

$\begin{aligned} \text { (DEG) } & =64.7000 \\ \text { (FT/SEC) } & =-9.6733 \\ \text { (PSI) } & =-650.8982 \\ (F T / S E C) & =-7.9200 \\ \text { (DSI) } & =-532.9193\end{aligned}$


SLAM CODE MO188 Check VALVE slam PRESSURe gurge.

THIS IS A SAMPLE PRORLEM OF AN ARTICULATED SWING TYPE CHECK

VALVE FOR THE SLAM (MO18B) CODE.

THE OPTIONS CHOSEN ARE

OPTION $1=1$ OPTION $2=0$ OPTION $3=1$ OPTION $4=0$

INPUT EDIT.

SPEED OF SOUND

DISC ANGLE FOR PIVOT CHANGE

DISC VOLUME

DISC INERTIA

CONVERGENCE CRITERION

DENSITY OF FLUID (LBS/FT CUBE) =

FULL CLOSED ANGLE FROM VERTICAL (DEG)

$(D E G)=$

(IN $C U B E)=$

PIVOT TO CG ARM AFTER PIVOT CHANGE (IN)

SPRING CONSTANT (IN-LAS/DEG)

SPRING CONSTANT AFTER CHANGE (INMLRS/DEG) a

$(T N-1 B-S E C S O)=$

DISC INERTIA AFTER CHANGE (IN-LS-SEC SO):

$(1$ SEC SO) $=$
$(I N S Q)=$

62.4000

5000.0000

$-20.0000$

30.0000

60.0000

5.0000

6.0000

0.0000

0.0000

7.0000

10.0000

0.0500

75.0000

DRAG

\begin{tabular}{cr}
\multicolumn{2}{c}{ COEFFICIENT } \\
ANGLE \\
-30.0000 & VALUE \\
85.0000 & 1500.0000 \\
0.0000 & 0.0090 \\
0.0000 & 0.0000 \\
0.0000 & 0.0000 \\
0.0000 & 0.0000 \\
0.0000 & 0.0000 \\
0.0000 & 0.0000 \\
0.0000 & 0.0000 \\
0.0000 & 0.0000 \\
0.0000 & 0.0000 \\
0.0000 & 0.0000 \\
& 0.0000
\end{tabular}

ANGLE

0.0000

0.0000

0.0000

0.0000

0.0000

0.0000

0.0000

0.0000

0.0000

0.0000

0.0000

0.0000

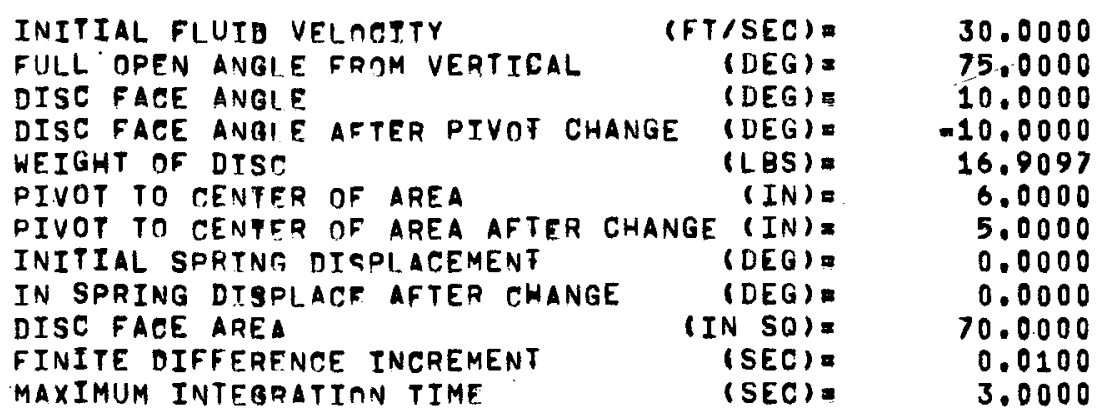

ADDED INERTIA

DUE TO WATER

VALUE
0.0000

0.0000

0.0000

0.0000

0.0 non

0.0000

0.000 ?

0.0000

0.0000

0.0001

0.0000

0.0000
TIME,

HATER

TIME,
0.0000
1.2500
3.0000
0.0000
0.0000
0.0000
0.0000
0.0000
0.0000
0.0000
0.0000
0.0000
VELOCITY

VELOCITY

30.0000
-25.0000
-25.0000
0.0000
0.00000
0.0000
0.0000
0.0000
0.0000
0.0000
0.0000
0.0000


SLAM CODE M0188 CHECK VAI.VE SLAM PRESSURE SURGE.

THIS IS A SAMPLE PROBLEM OF AN ARTICULATED SWING TYPE CHECK

VALVE FOR THE SLAM (MO18B) CODE.

OUTPUT

\begin{tabular}{|c|c|c|c|c|c|c|c|c|}
\hline TIME & $\begin{array}{l}\text { ANGLE OF } \\
\text { DISC }\end{array}$ & $\begin{array}{l}\text { DISC } \\
\text { ANGULAR }\end{array}$ & $\begin{array}{c}\text { DISC } \\
\text { ANGULAR }\end{array}$ & $\begin{array}{l}\text { WEIGHT } \\
\text { MOMENT }\end{array}$ & $\begin{array}{l}\text { FLOW } \\
\text { MOMENT }\end{array}$ & $\begin{array}{l}\text { SPRING } \\
\text { MOMENT }\end{array}$ & $\begin{array}{l}\text { INERTIA } \\
\text { MOMENT }\end{array}$ & $\begin{array}{l}\text { WATEK } \\
\text { VELOCLTY }\end{array}$ \\
\hline (SEC) & $\begin{array}{l}\text { FROM VERT } \\
\text { (DEGREES) }\end{array}$ & $\begin{array}{l}\text { VELOCITY } \\
\text { (RAD/SEC) }\end{array}$ & $\begin{array}{l}\text { ACCELER } \\
\text { (RAD/SEC SO) }\end{array}$ & $(I N-L B S)$ & (IN-LAS) & $(I N-L B S)$ & $(I N-L B S)$ & (FT/SEC) \\
\hline $\begin{array}{l}0.102 \\
0.202 \\
0.302 \\
0.402 \\
0.502 \\
0.602 \\
0.702 \\
0.802\end{array}$ & $\begin{array}{l}64.5147 \\
63.1115 \\
59.6870 \\
54.0733 \\
46.5746 \\
37.5839 \\
26.8519 \\
13.2864\end{array}$ & $\begin{array}{l}-0.1053 \\
-0.4078 \\
-0.7916 \\
-1.1577 \\
-1.4458 \\
-1.6976 \\
-2.0827 \\
-2.9200\end{array}$ & $\begin{array}{l}-2.2222 \\
-3.6264 \\
-3.8965 \\
-3.3115 \\
-2.5041 \\
-2.8628 \\
-4.7641 \\
-23.6930\end{array}$ & $\begin{array}{l}-66.5399 \\
-65.7431 \\
-63.6342 \\
-59.6893 \\
-53.5342 \\
-44.9578 \\
-33.2939 \\
-16.9400\end{array}$ & $\begin{array}{r}50.9845 \\
40.3580 \\
36.3584 \\
36.5085 \\
36.0052 \\
24.9182 \\
-0.0550 \\
-149.0109\end{array}$ & $\begin{array}{l}0.0000 \\
0.0000 \\
0.0000 \\
0.0000 \\
0.0000 \\
0.0000 \\
0.0000 \\
0.0000\end{array}$ & $\begin{array}{r}-15.5554 \\
-25.3851 \\
-27.2757 \\
-23.1808 \\
-17.5289 \\
-20.0395 \\
-33.3489 \\
-165.8509\end{array}$ & $\begin{array}{r}25.5267 \\
21.1467 \\
16.7267 \\
12.3267 \\
7.9267 \\
3.5267 \\
-0.8133 \\
-5.2133\end{array}$ \\
\hline
\end{tabular}

THE ARTICULATED VALVE has CHANGED PIVOTS AT THIS POINT. 
THIS IS A SAMPLE PROBLEM OF AN ARTICULATED SWING TYPE CHECK VALVE FOR THE SLAM (MO188) CODE.

OUTPUT

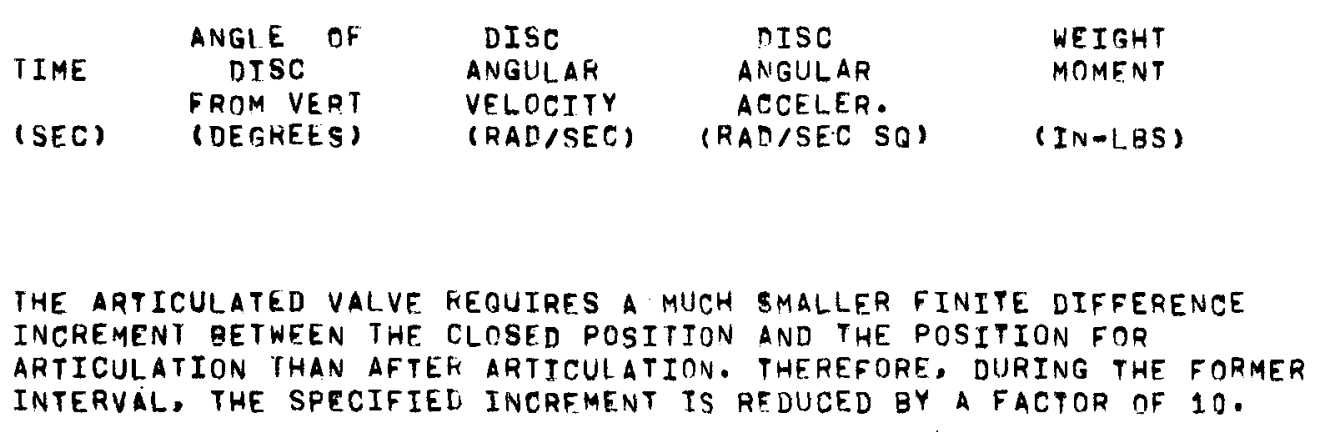

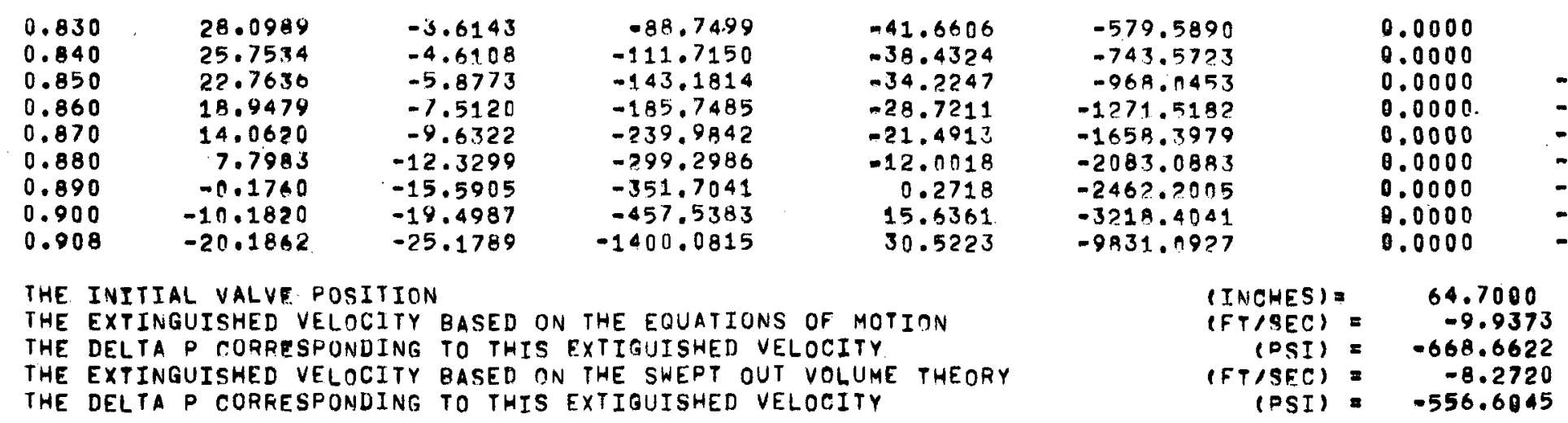

